\title{
Health Effects of Phenolic Compounds Found in Extra-Virgin Olive Oil, By-Products, and Leaf of Olea europaea L.
}

\author{
Annalisa Romani ${ }^{1, *}$, Francesca Ieri ${ }^{1}$, Silvia Urciuoli ${ }^{1}$, Annalisa Noce ${ }^{2, *} \mathbb{C}$, Giulia Marrone ${ }^{2,3}$ (D), \\ Chiara Nediani ${ }^{4}(-)$ and Roberta Bernini ${ }^{5}$ \\ 1 PHYTOLAB (Pharmaceutical, Cosmetic, Food Supplement, Technology and Analysis)-DiSIA, University of \\ Florence, Via U. Schiff, 6, 50019 Sesto Fiorentino, Italy \\ 2 UOC of Internal Medicine-Center of Hypertension and Nephrology Unit, Department of Systems Medicine, \\ University of Rome Tor Vergata, Via Montpellier 1, 00133 Rome, Italy \\ 3 PhD School of Applied Medical, Surgical Sciences, University of Rome Tor Vergata, via Montpellier 1, \\ 00133 Rome, Italy \\ 4 Department of Experimental and Clinical Biomedical Sciences "Mario Serio", University of Florence, \\ Viale Morgagni 50, 50134 Florence, Italy \\ 5 Department of Agriculture and Forest Sciences (DAFNE), University of Tuscia, Via San Camillo de Lellis, \\ 01100 Viterbo, Italy \\ * Correspondence: annalisa.romani@unifi.it (A.R.); annalisa.noce@uniroma2.it (A.N.); \\ Tel.: +39-055-457377 (A.R.); +39-06-20902188 (A.N.); Fax: +39-055-2751525 (A.R.); +39-06-20902096 (A.N.)
}

Received: 14 July 2019; Accepted: 28 July 2019; Published: 1 August 2019

\begin{abstract}
Olea europaea L. fruit is a peculiar vegetal matrix containing high levels of fatty acids (98-99\% of the total weight of extra-virgin olive oil, EVOO) and low quantities (1-2\%) of phenolics, phytosterols, tocopherols, and squalene. Among these minor components, phenolics are relevant molecules for human health. This review is focused on their beneficial activity, in particular of hydroxytyrosol (HT), oleuropein (OLE), oleocanthal (OLC), and lignans found in EVOO, olive oil by-products and leaves. Specifically, the cardioprotective properties of the Mediterranean diet (MD) related to olive oil consumption, and the biological activities of polyphenols recovered from olive oil by-products and leaves were described. Recent European projects such as EPIC (European Prospective Investigation into Cancer and Nutrition) and EPICOR (long-term follow-up of antithrombotic management patterns in acute coronary syndrome patients) have demonstrated the functional and preventive activities of EVOO showing the relation both between cancer and nutrition and between consumption of EVOO, vegetables, and fruit and the incidence of coronary heart disease. The data reported in this review demonstrate that EVOO, one of the pillars of the MD, is the main product of Olea europaea L. fruits; leaves and by-products are secondary but precious products from which bioactive compounds can be recovered by green technologies and reused for food, agronomic, nutraceutical, and biomedical applications according to the circular economy strategy.
\end{abstract}

Keywords: Olea europaea L.; extra-virgin olive oil; olive oil by-products; olives leaf; phenolic compounds; hydroxytyrosol; oleuropein; oleocanthal; lignans; health effects; circular economy

\section{Introduction}

Olea europaea L. is a fruit tree native to Asia Minor and Syria, which today is cultivated in the entire Mediterranean area; nowadays, the major producers of olives and olive oil are Spain, Italy, and Greece. Extra-virgin olive oil (EVOO), extracted physically from the fruit, is known for its nutritional properties and health effects, especially against cardiovascular diseases (CVDs). These properties are due 
to the presence of high levels of fatty acids (98-99\% of the total weight of EVOO), in particular of monounsaturated acids such as oleic, as well as of other valuable components like phenolics, phytosterols, tocopherols, and squalene even if present in low percentages (1-2\%). Only EVOO, and not all seed oils, has a high percentage of fatty acids with a correct balance of unsaturated fatty acids stabilized by minor polar compounds, with an antioxidant character [1].

All components of EVOO may potentially contribute to "health maintenance" [2]. Several international organisms regulate the quality and purity of EVOO, namely the European Union (EU), the International Olive Council (IOC), and the Codex Alimentarius according to data compiled by the Unaprol Economic Observatory [3].

Tree cultivars, their growing conditions, and the techniques used for EVOO production, are key factors for the quality of EVOO, affecting both its qualitative and quantitative characteristics, which can influence the sensorial and health properties of the oil. Advanced analytical techniques, such as high-performance liquid chromatography coupled to a diode array or a mass detector (HPLC-DAD, HPLC-MS), have played an important role in identifying and quantifying the bioactive compounds found in EVOO, which are responsible for its beneficial effects.

Among the minor components, the phenolic ones are relevant for the health effects attributed to EVOO (Table 1) [1]. In particular, epidemiological studies indicate that dietary consumption of phenol enriched EVOO has a cardioprotective effect in Mediterranean populations. The minor polar compounds include different subclasses among these: secoiridoids that are the dialdehydic form of decarboxymethyl elenolic acid linked to ortho-diphenolic and/or phenolic alcohols, such as OLE aglycone and oleacein, deacetoxyoleuropein, oleocanthal (OLC) (tyrosol linked to elenolic acid), and traces of ligstroside aglycon (tyrosol linked to elenolic acid). Another class is represented by phenolic alcohols, with hydroxytyrosol (HT), and tyrosol (TYR), together with their secoiridoid precursors and traces of phenolic acids such as gallic acid, protocatechic acid, $p$-hydroxybenzoic acid, vanillic acid, caffeic acid, syringic acid, $p$ - and $o$-coumaric acid, ferulic acid, and cinnamic acid. The flavonoids class is represented in traces; luteolin and apigenin are the flavones found in greater amounts. The last class is composed of lignans, and the most representative compounds in EVOO are acetoxypinoresinol and pinoresinol [3]. Among the minor polar compounds, HT and OLE are widely studied; in addition to the recently investigated OLC, they have been studied for their specific anti-inflammatory properties. In detail, HT and OLE (Figure 1) are valuable compounds for their high antioxidant capacity and for metal-chelating and free radical scavenging activities. HT is a molecule containing an ortho-diphenolic group that plays a significant role in EVOO. Its high antioxidant activity is due to its ability to scavenge reactive oxygen species (ROS) and stabilize oxygen radicals with an intramolecular hydrogen bond [4]. The above described lignans, pinoresinol and acetoxypinoresinol, also show antioxidant capacity [5].

Interestingly, during fruit maturation and olive oil production, the enzymatic systems present in the fruit are able to hydrolyze OLE first into its aglycone form, and then into HT together with glucose and elenolic acid, as depicted in Figure 2 [6]. Due to its hydrophilic character, HT is abundant in olive oil by-products and in particular in olive oil wastewaters, thus representing a precious source from which to extract this valuable compound [7].

This review is focused on the description of the beneficial effects of the main polyphenols found in EVOO, olive oil by-products and olive leaf, analyzing the beneficial properties of HT and OLE in detail.

The extraction procedures used to retrieve polyphenols from olive waste, leaf, and the fruit have recently been improved, and traditional systems have been optimized by newer technologies such as membrane separation techniques developed to fractionate olive mill wastewaters. The benefits achieved with the newer methods include lower energy consumption and no necessary additives or phase change $[4,8]$. 
Table 1. Subclasses of EVOO minor polar components

\section{EVOO Minor Polar Components}

\begin{tabular}{cl}
\hline \multirow{5}{*}{ Secoiridoids } & $\begin{array}{l}\text { (a) Oleuropein aglycone } \\
\text { (b) Deacetoxy oleuropein } \\
\text { (c) Oleocanthal and oleacin }\end{array}$ \\
& (d) Ligstroside aglycone \\
\hline \multirow{5}{*}{ Phenolics } & (a) Hydroxytyrosol \\
& (b) Tyrosol \\
& (c) Hydroxytyrosol glycole \\
& (a) Gallic acid \\
& (b) Protocatechuic acid \\
& (c) p-Hydroxybenzoic acid \\
(d) Vanillic acid \\
(e) Caffeic acid \\
& (f) Syringic acid \\
& (g) p-and o-coumaric acid \\
& (h) Ferulic acid \\
& (i) Cinnamic acid \\
\hline \multirow{2}{*}{ Flavonoids } & (a) Luteolin \\
& (b) Apigenin \\
\hline \multirow{2}{*}{ Lignans } & (a) (+) Pinoresinol \\
& (b) (+) Acetoxypinoresinol
\end{tabular}

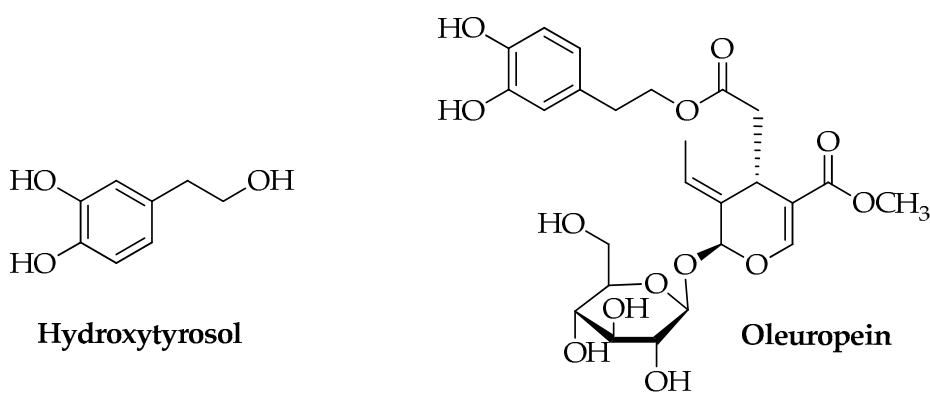<smiles>C/C=C(/C=O)[C@H](CC=O)CC(=O)OCCc1ccc(O)cc1</smiles>

(-)-Oleocanthal<smiles>COc1cc([C@@H]2OC[C@@H]3[C@H]2CO[C@H]3c2ccc(O)c(OC)c2)ccc1O</smiles>

(+)-Pinoresinol<smiles>COc1cc([C@@H]2OC[C@@H]3[C@H]2CO[C@H]3c2ccc(O)c(OC)c2)ccc1O</smiles>

(+)-1-Acetoxypinoresinol

Figure 1. Chemical structure of the main phenolic compounds found in Olea europaea L. 


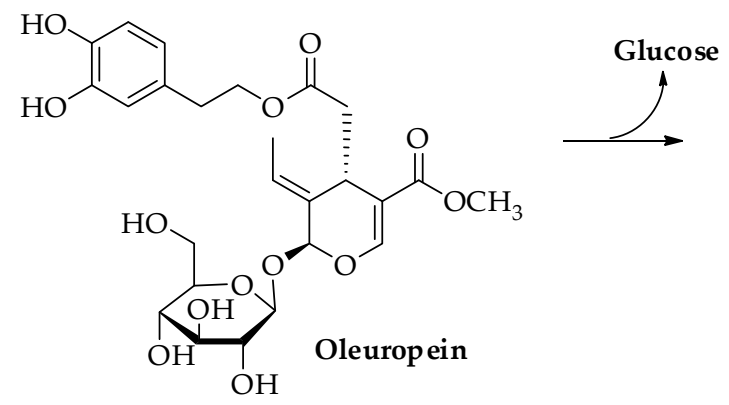<smiles>COCC(=O)O/C=C\[C@@H]1C(C(=O)OC)=CO[C@@H]1O</smiles>

Oleurop ein aglycone

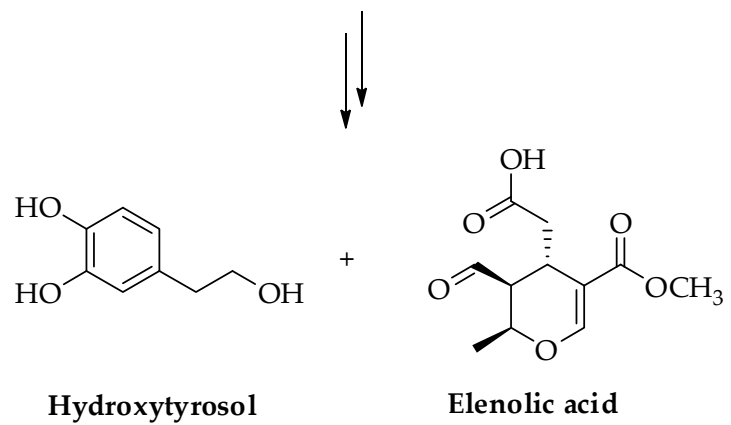

Figure 2. Enzimatic conversion of oleuropein into hydroxytyrosol.

This paper envisages the characterization and use of EVOO as a natural functional food, and the characterization and use of active extracts/ingredients obtained from olive leaf, pitted and de-oiled olive paste and juices, and from secondary matrixes (olive biphasic pomace and leaf), through sustainable green technologies. Fractions enriched in EVOO's minor polar compounds, in OLE from leaf and in HT from de-oiled and pitted olive paste and the lipophilic derivatives, will be characterized and described from the chemical point of view, as quali-quantitative content in bioactive components and for their biological and nutraceutical activities (Figure 3).

The technical, economic, and environmental evaluation of the Olea europaea L. platform requires a material and energy flow analysis of the production cycle. The methodology used is the Membrane Filtration Absorption (MFA), which can evaluate the energy and material flows in a well identified system $[9,10]$ that is the production process of the polyphenols from Olea europaea L., accounting for the inputs (consumption of material and energy resources consumption) and the outputs (waste products) of the process.

Data and methods concern the extraction of polyphenols from olive oil by-products based on new sustainable technologies with a water extraction and membrane separation system. Previously, scientific reports considered the same procedure for olive-oil waste-water polyphenol purification at a laboratory scale $[11,12]$. This innovative industrial process has instead been implemented at an industrial level by using physical technologies defined as BAT (Best Available Technology) and recognized by the EPA (Environmental Protection Agency) [13,14].

In the production process, the yield in quality EVOO, stands near 10-14\%. Generally, the recovery process is based on membrane technologies applied to aqueous extracts obtained in a pneumatic extractor and then purified by filtration. The first phase of olive-oil production, from olives to oil and wet pomace, has only been considered in the material data (as Figure 2 shows) and it emerges that from the processed olives, by the use of a two-phases system, the wet-pomace can be extracted at the rate of $80 \%$ [15]. The remaining share represents the EVOO and olive oil (near $20 \%$ ). Regarding the process, from wet olive pomace to the main output, the yield is very low and approximately $4.4 \%$. The Olea by-products recovery process includes demineralized/pure water production and a final reverse osmosis (RO) phase. The chemical recovery and the production of energy should be a continuous process of interaction between green technology and environmental and economic sustainability, making this integrated platform highly innovative and consistent with the principles of 
the circular economy, with the development of new business activities. The results have highlighted that this platform can produce up to $6000 \mathrm{~kg}$ of standardized polyphenol fractions, useful in food and nutraceutical application; moreover, each residue of the process (water, olive cores, destoned pulp) comes into an innovative use in the same and/or other processes according to the circular economy models. The conclusion underlines the main positive features of this sustainable model, the eco-innovation of the process and the economic and environmental advantages consisting in reducing waste, water, and energy consumption. Operating plants that produce standardized natural fractions in HT and OLE contents, are in Spain and Italy and commercial fractions, in sharp increase in consumption are, for example, Phenolea Active, and OleaFit ${ }^{\mathrm{TM}}$ standardized in various bio-active compounds content.
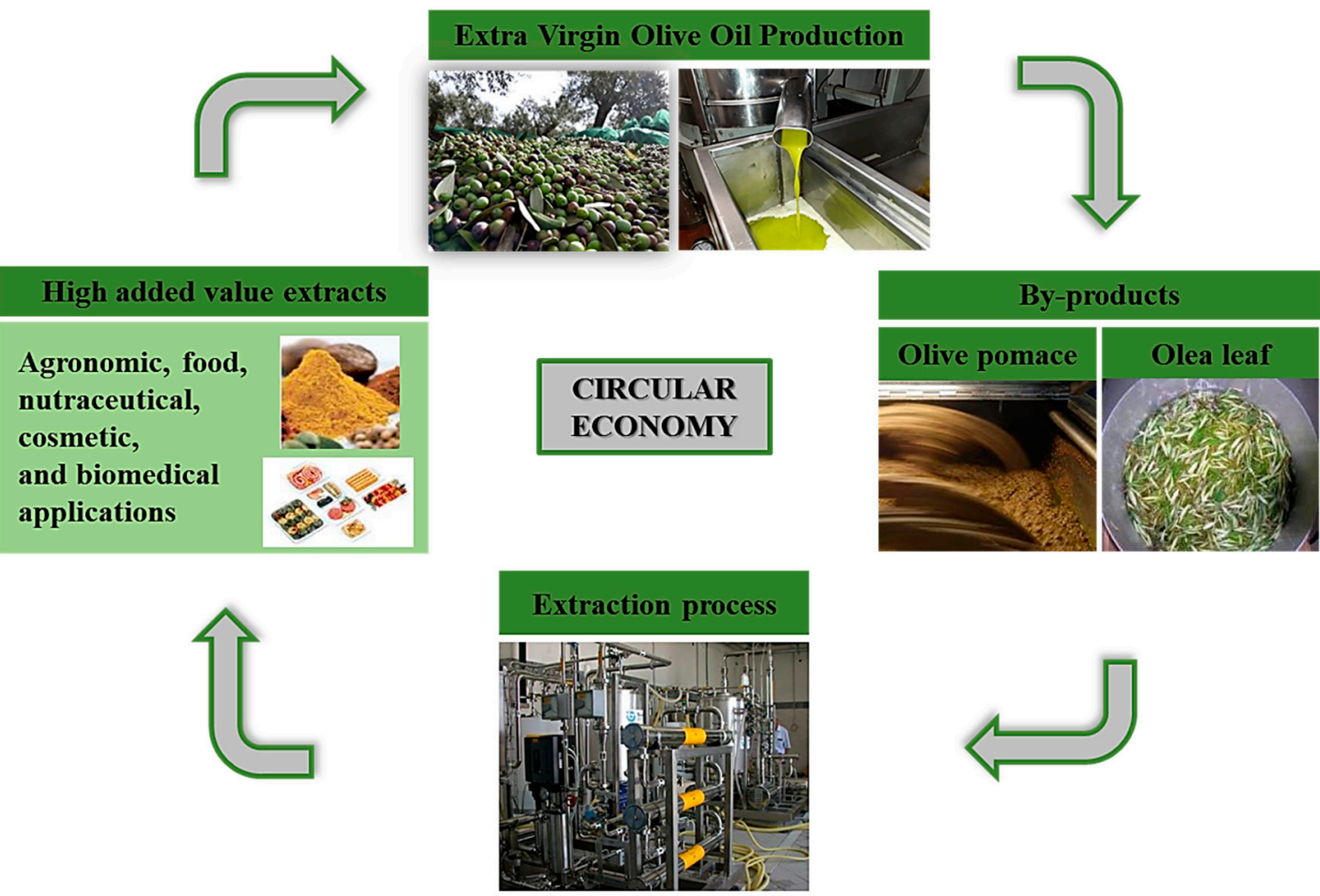

Figure 3. Circular economy platform based on green technologies, for the recovery of active molecules from olive leaf and processing by-products, useful in the food, nutraceutical, cosmetic, and biomedical fields.

\section{Methods}

Current literature analyzing the beneficial effects of the minor polar compounds of EVOO has been contextualized in this review. Specifically, the search was conducted using digital libraries such as Medline (Pubmed) and Scopus. The search examined studies published until May 2019, utilizing the words: Olea europaea L. minor polar compounds of extra-virgin olive oil, HT, OLE, OLC, lignans, biological activities of extra-virgin olive oil, and Olea by-products. Specific research related to the topic of this review carried out by all authors was also described.

\section{Health Effects of Phenolic Compounds Found in Extra-Virgin Olive Oil (EVOO)}

The cardioprotective properties of the Mediterranean diet (MD), related mostly to the beneficial effects of EVOO, were demonstrated for the first time in the Seven Country Study of Cardiovascular Disease (SCSCD) [16]. The MD consists of a balanced consumption of fruit, vegetables, legumes, and cereals, associated with a large assumption of bluefish and EVOO (the last as the main source of fats), reduced consumption of red meat and dairy products, and moderate intake of alcohol, mainly 
red wine. The MD has an important effect on maintaining health and increasing longevity, as cited by the United Nations Educational Scientific and Cultural Organization (UNESCO) in 2010 [17,18].

In the last few decades, numerous epidemiological studies [19] and meta-analyses [20], as well as intervention trials [21-23], confirmed this observation, pointing out the protective role of the MD on primary [24] and secondary [25] prevention of CVDs (Figure 4).

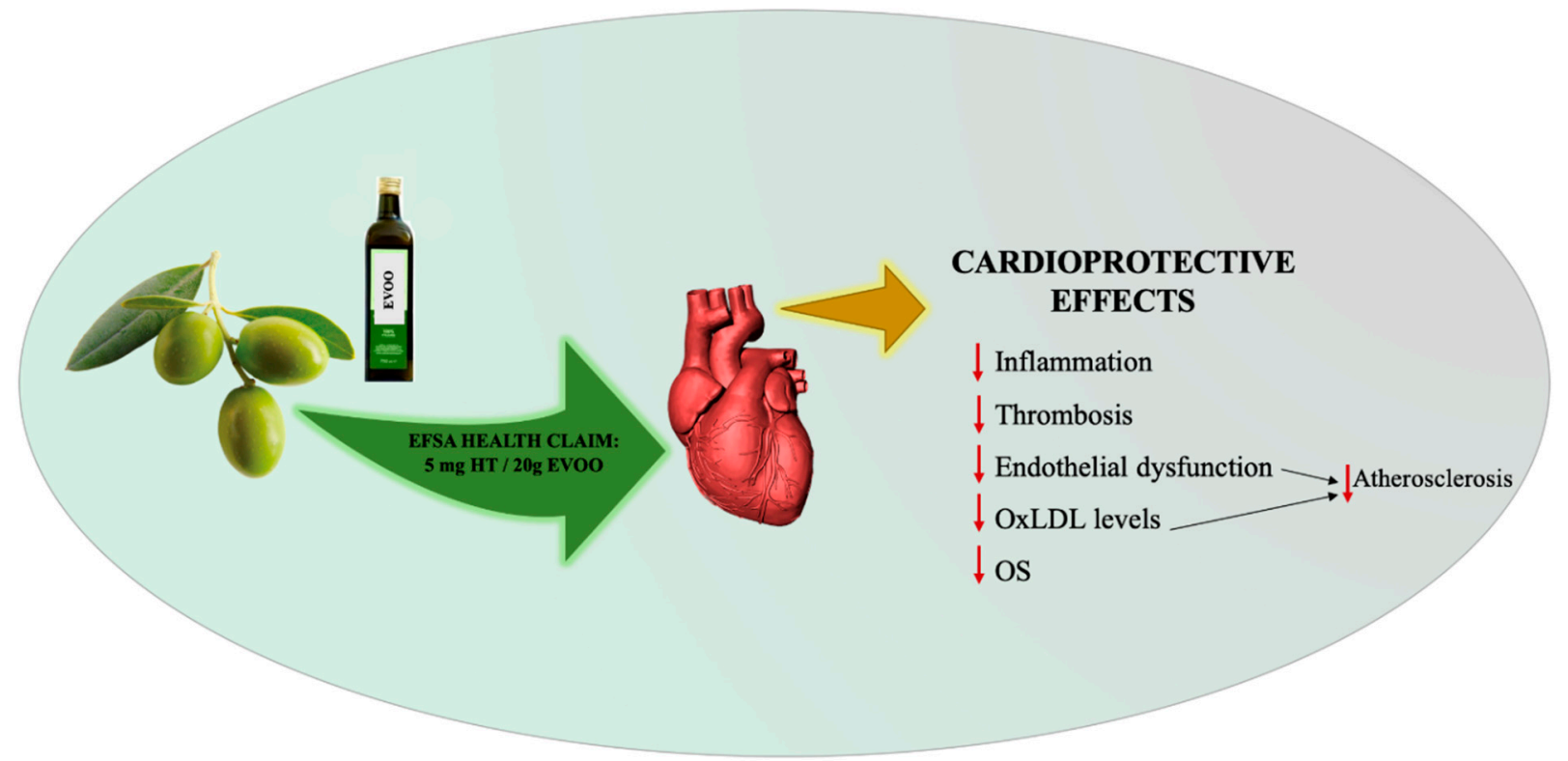

Figure 4. EVOO and its cardioprotective action on the CV system. EVOO, Extra-virgin olive oil; HT, hydroxytyrosol; OxLDL, oxidized LDL; OS, oxidative stress.

The PREDIMED study investigated, on 7477 subjects at high risk of CVDs, the protective effect of the MD supplemented with EVOO or nuts on major cardiovascular (CV) events (such as stroke, myocardial infarction, or death from CV causes). The authors highlighted that the incidence of major CV events was significantly decreased in subjects following the MD supplemented with EVOO or nuts compared to those following a reduced-fat diet, confirming the beneficial effects of the MD for primary CV prevention [24].

A prospective randomized trial [25] compared a MD enriched with alpha-linoleic acid to a prudent diet, in regards to their respective effects on secondary prevention after myocardial infarction, concluding that the alpha-linoleic acid-enriched MD was more effective in secondary prevention of acute coronary events and death, since it has been hypothesized that linoleic acid reduces the incidence of fatal arrhythmias [26].

In our study, we observed for the first time the health effects of the Italian Mediterranean diet (IMD) and the Italian Mediterranean organic diet (IMOD) in healthy subjects and in stage II-III chronic kidney disease (CKD) patients, staged according to the Kidney-Disease Outcomes Quality Initiative (K-DOQI) guidelines [27]. Specifically, we demonstrated a significant reduction of phosphorus, total homocysteine (Hcy), and albuminuria, as well as an improvement of body composition (a significant increase in lean mass percentage and a decrease in fat mass both in $\mathrm{kg}$ and in percentage) after two weeks of IMOD treatment. The improvement of all these clinical parameters is associated with lower CV risk, highlighting the role of the IMOD in the prevention of CVDs [22]. The IMOD would seem to induce a slowing down of CKD progression.

In our study, we subsequently confirmed that the IMOD in CKD patients on conservative therapy represents a useful tool for the prevention of CVDs, inducing a significant reduction of serum Hcy influenced by the methylenetetrahydrofolate reductase (MTHFR) genotype [23]. Hcy causes endothelial 
dysfunction through production of ROS, which occurs during the autoxidation process, accelerating atherosclerosis $[28,29]$.

In 2011, the European Food Safety Authority approved some claims reported by the Commission Regulation no. 432/2012 concerning the benefits of bioactive compounds found in foods including EVOO phenols and, in particular, of HT and OLE, supporting their relevant role for human health [30]. The health effects are protection of LDL from oxidative damage, maintenance of normal blood HDL cholesterol concentrations, maintenance of normal blood pressure, anti-inflammatory properties, contribution to upper respiratory tract health, maintenance of normal gastrointestinal tract function, and contribution to body defenses against external agents. These beneficial effects are obtained with a daily intake of $20 \mathrm{~g}$ of EVOO, containing $5 \mathrm{mg}$ of $\mathrm{HT}$ and its derivatives [31]. Indeed, the oxidized LDLs (OxLDLs) binding with the receptor LOX-1 (receptor OxLDL-lectin-similar to receptor-1), stimulate endothelial expression and secretion of pro-atherogenic enzymes. This bond induces the production of superoxide and the reduction in local nitric oxide (NO) concentration. LOX-1, which causes a rapid rise in ROS levels through membrane-bound NADPH oxidase (NOX), is a specific endothelial scavenger receptor involved in the initial process of atherosclerotic plaque formation [32].

EVOO extracts were tested in vitro on human endothelial cells (HUVEC) to evaluate their antioxidant capacity [33] and their ability to modulate the cellular expression of ICAM-1 and VCAM-1 in a pro-inflammatory environment, in order to investigate their anti-atherogenic effects [34]. In order to better understand the differences among the in vitro and in vivo effects of EVOO, it will be necessary to compare various monocultivar in phenolic content.

Despite the biological activities of dietary phenolics, only a few studies have been carried out to investigate their absorption in humans after ingestion. A specific study on olive oil phenolics was performed by Visioli et al. [35], demonstrating that they were absorbed in humans and excreted in the urine as glucuronide.

As far as the biological activities of olive oil are concerned, a review by Covas et al. [36] examined 15 human studies and the majority indicate that olive oil (rich in phenols) is superior to seed oils and olive oil with low-phenol content. This superiority was attributed to the reduction of CV risk factors, such as reduced plasma LDL, improved endothelial function and a decreased prothrombotic environment.

Polyphenolic metabolites of EVOO after ingestion were methylated, sulfonated, or glucorinated; in vitro studies $[37,38]$ have shown that these metabolic modifications do not inhibit their biological activities in humans. Moreover, the parent compounds and the metabolites derived from EVOO are capable of reaching a concentration at tissue level (mainly in the gastrointestinal and CV systems) able to exert antioxidant and anti-inflammatory actions, by modulating intracellular signaling [39].

Pharmacological studies concerning the activities of phenolic compounds are increasing, since they seem to have potential cardioprotective and chemopreventive actions.

HT and OLE are able to inhibit copper-induced LDL oxidation at low concentrations and show a powerful ability to chelate metals and scavenge free radicals [26,27]. In particular, a specific study carried out by Franconi et al. [40] demonstrated that the concentration capable of reducing copper-induced LDL is similar to that measured in human plasma after EVOO intake [40,41].

A study on 10 healthy postmenopausal women compared the effects of high-phenol EVOO (592 $\mathrm{mg}$ total phenols $/ \mathrm{kg}$ ) with a low-phenol EVOO (147 mg total phenols $/ \mathrm{kg})$. Daily dose of EVOO was 50 $\mathrm{g}$ per day for a period of 8 weeks. Oxidative DNA damage was evaluated by monitoring peripheral blood lymphocytes. Subjects who took high-phenol EVOO had oxidative DNA damage reduced by $30 \%$ compared to subjects treated with low-phenol EVOO. This study demonstrated a protective role of EVOO phenols on oxidative damage in healthy postmenopausal women. Moreover, subjects who consumed high-phenol EVOO had a significantly increased urinary excretion of HT compared to low-phenol EVOO [42].

These data were confirmed in a randomized trial in 200 healthy male subjects that evaluated the effects of olive oil phenol content on lipid oxidative damage and plasma lipid levels. The enrolled subjects were randomized into three groups based on the content of phenols in olive oil and took $25 \mathrm{~mL}$ 
of oil per day for a total of 3 weeks. The three types of olive oil were the following: low-phenol olive oil (2.7 mg/kg of olive oil), medium-phenol olive oil (164 mg/kg of olive oil), and high-phenol olive oil $(666 \mathrm{mg} / \mathrm{kg}$ of olive oil). The authors highlighted that the biomarkers of oxidative stress were reduced proportionally to the phenol content, while the HDL-cholesterol levels increased directly to the phenol content of the olive oil. Triglycerides were reduced in all the three groups examined. Therefore, this study confirmed that phenolic content improves lipid oxidative damage and lipid profile [43]. Several studies showed that a constant consumption of EVOO is associated with a reduction in the molecules involved in inflammatory processes related to atherosclerosis, by the downregulation of NF-kB [44,45].

The close correlation between inflammation, endothelial dysfunction, and CVDs is well known [46,47]. In the study conducted by Brunelleschi et al. [48], phenolic-rich EVOO inhibits, in a concentration-dependent manner, the nuclear translocation of the p50 and p65 subunits of the NF- $\kappa B$ complex within monocytes and monocyte-derived macrophages (MDM) of healthy subjects. This inhibitory effect was especially evident when the cells were stimulated by phorbol-myristate acetate (PMA) and obtained at EVOO extract concentrations similar to those measured in human plasma after a daily ingestion of EVOO. This inhibitory action is comparable to the effect exerted by ciglitazone, a PPAR- $\gamma$ ligand.

Moreover, OLE, the most abundant polyphenol in EVOO, has shown to significantly increase lipopolysaccharide (LPS)-induced NO production, a bactericidal and cytostatic agent whose heightened expression increases macrophages' functional activity [49].

Western blot analysis of cell homogenates, and coincubation of bacterial LPS challenged cells with L-nitromethylarginine methylester (a nitric oxide synthase, iNOS inhibitor), showed how OLE directly stimulates the inducible form of the iNOS enzyme, leading to the above-mentioned enhancement of macrophage function [49].

The incidence of chronic illnesses related to aging and unhealthy lifestyles is on the rise, but increasing data are showing how the intake of secoiridoid-rich EVOO may help to prevent or even treat chronic non-communicable diseases (NCDs), in which the inflammatory component is directly involved in their onset and progression [50,51].

Another secoiridoid of considerable interest is OLC because recent studies have highlighted its pharmacological properties and its mechanisms of action, showing the preventive effect on inflammation, oxidative stress, specific types of cancer, neurodegenerative and rheumatic diseases. OLC is one of the components of EVOO and it is responsible for the pungent character of this food. This perception seems to be due to the presence of a specific OLC receptor present in the oropharyngeal region [52]. This receptor seems to be the transient receptor potential channel, subfamily A, member 1 (TRPA1) [53]. It is hypothesized that the different sensitivity in the perception of the pungent taste of OLC may be related to the inter-individual variations in the expression of the TRPA1 receptor in the oropharynx [53]. This sensation is similar to that observed after taking ibuprofen (non-steroidal anti-inflammatory drug), and from this observation, some authors have hypothesized that the two substances could have the same biological activity [54]. Despite the structural differences, both molecules inhibit the same cyclooxygenase enzymes involved in the biosynthesis of prostaglandins. In detail, both OLC enantiomers induce the inhibition of cyclooxygenase (COX) 1 and 2, but in vitro have no effect on lipoxygenase. The inhibition of COX 1 and 2 is dose-dependent: an OLC concentration equal to $25 \mu \mathrm{M}$ inhibits COX activity by $41 \%$ and $57 \%$ vs. $25 \mu \mathrm{M}$ of ibuprofen which inhibits COX by $13 \%$ to $18 \%$, respectively [55].

Therefore, the authors have hypothesized that the long-term consumption of OLC may protect against the onset of certain pathological conditions, due to its biological action similar to ibuprofen [56,57]. The dosage that seems to be active is $9 \mathrm{mg}$ per day, which corresponds to $10 \%$ of the dose of ibuprofen taken by adults to counteract pain. In the literature, it is known that a constant low dose of aspirin (another COX -inhibitor) induces CV protection [54]. Therefore, it is hypothesized that a long-term OLC consumption may also exert a cardioprotective action. 
To date, the OLC-induced cardioprotective action has been little investigated. In fact, a single study highlights the possible protective effects of OLC in atherosclerotic CV disease [58]. This disease is a chronic inflammatory process that affects the vessel walls and begins with damage to the endothelium. Endothelial damage mainly involves platelets [58,59]. Recently, Agrawal K. et al. [60] have shown, in a randomized clinical trial, that the intake of $40 \mathrm{~mL}$ per week of EVOO rich in OLC can influence platelet aggregation responses in healthy male adults, confirming previous data obtained from animal studies [61]. Currently, the analytical methods for the OLC assay are not standardized and, in literature, not all the studies reporting the content of EVOO minor polar compounds show this data. Therefore, the value of $9 \mathrm{mg}$ per day is probable but not yet defined. The concentration of OLC is usually low in fresh EVOO and increases during EVOO storage due to hydrolysis of secoiridoids that enhance HT [39].

A study carried out by Carrrasco-Pancorbo et al. [62] has demonstrated the antioxidant activity of pinoresinol and acetoxypinoresinol using the DPPH (2,2-diphenyl-1-picrylhydrazyl) method and evidenced that the absence of the acetyl group in pinoresinol is relevant for its activity $[5,62]$. Further studies demonstrated that pinoresinol also shows in vitro anti-inflammatory activity [63]. In vitro studies show that both acetoxypinoresinol and pinoresinol have chemopreventive activity in breast cancer by decreasing the levels of fatty acids synthase in the HER2 gene that is over-expressed in breast cancer cells [64]. A study conducted in 2008 [65] demonstrated the capacity of pinoresinol, in synergy with other phenolic compounds present in olive oil extracts, in decreasing proliferation and inducing apoptosis of human colon cancer cells.

A limited number of available randomized controlled trials (RCTs), show EVOO's action in secondary prevention of diseases related to atherosclerosis and there are no RCTs aimed at assessing the minimum daily EVOO intake required in order to have an anti-inflammatory and cardioprotective action [66].

Evidence indicates that regular consumption of EVOO is associated with a reduced risk of developing NCDs. In the field of NCDs, disorders like cancer, CKD, arterial hypertension, and metabolic syndrome deserve a special mention [67].

The European Prospective Investigation into Cancer and Nutrition (EPIC) study has indicated the possible correlation between cancer and nutrition, examining lifestyle, nutritional status, type of diet, medical history, anthropometric parameters, and biological samples. This study was conducted on 521,000 subjects (one of the largest cohort studies in the world) enrolled from 23 centers in 10 western European countries. Following enrollment, the participants were contacted at regular intervals every 3-5 years (depending on the country or center) to obtain information on various aspects of their lifestyle, which may have changed over time. To date, the data collected indicates that the MD is the most effective food model in cancer prevention. There is also evidence that consumption of flavonoids reduces the risk of gastric cancer $[68,69]$.

The EPIC study Italian cohort, composed of 47.749 volunteers, was evaluated for eating habits and lifestyle. The authors concluded that the food pattern "Olive oil and Salad" food pattern, mainly based on the consumption of raw vegetables, EVOO and legumes is associated with lower mortality in the elderly and a lower risk of developing colorectal cancer. The latter has a lower incidence in regular yogurt consumers for the probable protective action exerted by probiotics against NCDs [70,71].

These data were confirmed in a cohort of 5,611 Italian elderly subjects (aged $\geq 60$ years), where a Cox model showed that a high consumption of olive oil, fresh vegetables, soup, and poultry was inversely correlated with mortality from all causes. On the other hand, the food pattern "Pasta and Meat" characterized by a high content of pasta, tomato sauce, red and processed meat, added animal fats, white bread, and wine was associated with an increase in mortality from all causes. The authors recommend a high consumption of olive oil, fresh vegetables, and poultry in the geriatric population due to its effects on health [72].

In the EPICOR (long-term follow-up of antithrombotic management patterns in acute coronary syndrome patients) study, the authors enrolled 29,689 Italian women from northern, central, and southern cities, evaluating the possible associations between assumption of EVOO, vegetables 
and fruit, and incidents of coronary heart disease (CHD). The mean follow-up period was 7.85 years. They demonstrated that women who consumed vegetables and olive oil in the highest quartile had a reduced risk of developing CHD. This study confirms the protective effect for CVDs in primary and secondary prevention, related to the consumption of vegetables and olive oil [73].

Our project called EXTRANUTRAOILS is evaluating the impact of EVOO with health claims (natural functional food) in CKD patients, to investigate the effects of high-phenol EVOO on the progression of CKD and its complications (Table 2).

\section{Impact of Olive Oil and Its Derivatives on Gut Microbiota Composition}

One of the most densely populated human ecosystems is the gastrointestinal tract. It boasts the presence of about $10^{13}$ microbial species within it, and is called the "gut microbiota" [74].

The study of the link between human gut microbiota and health status has attracted considerable interest in the scientific community over the past 15 years. It is essential to understand how different nutrients impact the gut microbiota composition which in turn influences the onset and progression of chronic non-communicable diseases [75]. Currently, the knowledge on the gut microbiota indicates that it can interact with the host both directly and indirectly. In fact, it is able to release bioactive molecules that modulate numerous biological responses, involving several systems and functions such as the immune system and/or energy homeostasis [76]. Some nutrients can influence the composition of gut microbiota; among these, we find olive oil and its derivatives [77].

Pallara G. et al. [78] evaluated the polyunsatured fatty acid (FA) profile derived from ruminant livestock, after the administration of feed supplemented with stoned olive pomace (SOP), which represents a waste deriving from the processes of conversion from olive or olive oil. They concluded that feeds supplemented with SOP decreased the production of unsaturated FA in a dose-dependent manner through the modification of gut microbiota composition. Therefore, functional lipids can be produced from meat and dairy products through animal feed supplementation.

N. Martinez et al. [79] performed an animal study to compare the effects of standard diets versus high fat diets (enriched with EVOO, refined olive oil or butter) diets, on gut microbiota composition. In order to evaluate the possible variations on gut microbiota caused by different diets, they sequenced mice fecal 16S rRNA. The group fed with a high fat-diet enriched with refined olive oil, showed significantly higher levels of total cholesterol compared to the EVOO diet group. Moreover, the high-fat diet enriched with refined oil group showed a greater presence of Desulfovibrionaceae, Spiroplasmataceae, and Helicobacteraceae families. The authors showed a direct relation between the quality of fats in the diet (in this case refined olive oil and EVOO), some laboratory parameters, and the presence of certain taxa. For this reason, it becomes increasingly clear that the minor polar compounds present in EVOO are able to positively modulate the gut microbiota. 
Table 2. Studies on extra virgin olive oil.

\begin{tabular}{|c|c|c|c|c|c|}
\hline \multicolumn{6}{|c|}{ Extra Virgin Olive Oil } \\
\hline Type of Study & Reference & Year & Type of Intervention & Primary Outcome & $p$-Value for Primary Endpoint \\
\hline \multirow{7}{*}{$\begin{array}{l}\text { In vitro cell } \\
\text { models }\end{array}$} & $\begin{array}{l}\text { Manna, C. } \\
\text { [41] }\end{array}$ & 2002 & $\begin{array}{l}\text { Evaluation of effects of phenolic fraction } \\
\text { extract from EVOO on oxidative damage } \\
\text { in human erythrocytes and Caco- } 2 \text { cells }\end{array}$ & $\begin{array}{l}\text { Protective effects of EVOO phenolic } \\
\text { fractions }\end{array}$ & $\begin{array}{l}\text { Linear relationship between antioxidant } \\
\text { capacity of EVOO phenolic fraction and } \\
o \text {-phenolic content. } \\
R^{2}=0.999\end{array}$ \\
\hline & $\begin{array}{l}\text { Beauchamp, G.K. } \\
\text { [54] }\end{array}$ & 2005 & $\begin{array}{l}\text { Evaluation of effects of oleocanthal as } \\
\text { modulator of inflammation and } \\
\text { analgesia }\end{array}$ & $\begin{array}{l}\text { Oleocanthal caused dose-dependent } \\
\text { inhibition of COX-1 and COX-2 activities. }\end{array}$ & - N.A. \\
\hline & $\begin{array}{l}\text { Carrasco- } \\
\text { Pancorbo, A. } \\
{[62]}\end{array}$ & 2005 & $\begin{array}{l}\text { Electrochemical study on the resistance } \\
\text { of oxidative deterioration of VOO } \\
\text { correlated to the presence of phenolic } \\
\text { compounds }\end{array}$ & $\begin{array}{l}\text { Ability of compounds isolated from } \\
\text { VOO by measuring the radical } \\
\text { scavenging effect on } \\
\text { 1,1-diphenyl-2-picrylhydrazyl radical }\end{array}$ & - N.A. \\
\hline & $\begin{array}{l}\text { Vuorela, S. } \\
\text { [63] }\end{array}$ & 2005 & $\begin{array}{l}\text { Phenolic extracts isolated from bioactive } \\
\text { sources have been studied for their } \\
\text { antioxidant, antimicrobial, } \\
\text { anti-inflammatory, and antimutagenic } \\
\text { properties. }\end{array}$ & $\begin{array}{l}\text { Phenolic extracts from oils, induced a } \\
\text { decrease of proinflammatory mediators } \\
\text { (prostaglandin E2). } \\
\text { All tested extracts were safe. In fact, they } \\
\text { did not stimulate mutagenic nor toxic } \\
\text { action on Caco-2 cells or macrophages. }\end{array}$ & - N.A. \\
\hline & & & & Expression of & \\
\hline & $\begin{array}{l}\text { Dell'Agli, M. } \\
\text { [34] }\end{array}$ & 2006 & $\begin{array}{l}\text { Evaluation of HT and OleA form EVOO } \\
\text { in HUVEC }\end{array}$ & $\begin{array}{ll}- & \text { ICAM-1 VCAM-1 at concentration } \\
& \left(\text { IC }_{50}<1 \text { micro } \mathrm{M}\right) \\
- & \text {-HVA } \\
- & \text {-E-selectin cell surface expression }\end{array}$ & $\begin{array}{l}\text { Downregulation of adhesion } \\
\text { molecules associated with } \\
\text { early atherosclerosis }\end{array}$ \\
\hline & $\begin{array}{l}\text { Franconi, F. } \\
\text { [40] }\end{array}$ & 2006 & $\begin{array}{l}\text { Whole virgin olive extracts studied to } \\
\text { determine whether they maintain the } \\
\text { antioxidant activity and whether this last } \\
\text { is linked to MPC composition of a single } \\
\text { virgin oil }\end{array}$ & $\begin{array}{l}\text { Evaluation of oils derived from Taggiasca } \\
\text { and Seggianese olive on human LDL }\end{array}$ & $\begin{array}{l}\text { - In both tests, the oil extracts } \\
\text { dose-dependently reduced } \\
\text { malondialdehyde and conjugated } \\
\text { diene generation } \\
\text { Seggianese extract was more active } \\
\text { with respect to Taggiasca extract. }\end{array}$ \\
\hline
\end{tabular}


Table 2. Cont.

\begin{tabular}{|c|c|c|c|c|c|}
\hline \multicolumn{6}{|c|}{ Extra Virgin Olive Oil } \\
\hline Type of Study & Reference & Year & Type of Intervention & Primary Outcome & $p$-Value for Primary Endpoint \\
\hline & $\begin{array}{l}\text { Brunelleschi, S. } \\
\text { [48] }\end{array}$ & 2007 & $\begin{array}{l}\text { Evaluation of EVOO extracts rich in } \\
\text { minor polar compounds (MPC-OOE) on } \\
\text { human cells }\end{array}$ & $\begin{array}{l}\text { NF-kB translocation in monocytes and } \\
\text { monocyte-derived macrophages } \\
\text { sampled from healthy subjects }\end{array}$ & $\begin{array}{l}\text { MPC-OOE extracts inhibits NF-kB } \\
\text { translocation in human monocytes } \\
\text { and MPC does not affect PPAR- } \gamma \text { in } \\
\text { human monocytes and MDM } \\
p<0.001\end{array}$ \\
\hline & $\begin{array}{l}\text { Menendez, J.A. } \\
\text { [64] }\end{array}$ & 2008 & $\begin{array}{l}\text { Evaluation of EVOO phenolic effects on } \\
\text { the expression of FASN in human breast } \\
\text { cancer epithelial cell lines. }\end{array}$ & $\begin{array}{l}\text { EVOO phenols: lignans, flavonoids, } \\
\text { and secoiridoids suppress FASN protein } \\
\text { expression in HER2 gene amplificated } \\
\text { SKBR3 breast cancer cells }\end{array}$ & $\begin{array}{l}\text { Extracts from EVOO can induce } \\
\text { anti-cancer effects in breast } \\
\text { cancer cells }\end{array}$ \\
\hline & $\begin{array}{l}\text { Fini, L. } \\
\text { [65] }\end{array}$ & 2008 & $\begin{array}{l}\text { Evaluation of anti-cancer effects of } \\
\text { EVOO phenolic extracts in cells lines for } \\
\text { two EVOOs. } \\
\text { (1). EVOO (A) pinoresinol as main } \\
\text { phenol } \\
\text { (2). EVOO (B) oleocanthal as main } \\
\text { phenol }\end{array}$ & $\begin{array}{l}\text { EVOO (A) has powerful } \\
\text { chemopreventive actions and } \\
\text { upregulates the ATM-p53 cascade }\end{array}$ & $\begin{array}{l}\text { EVOO (A) inhibits cell proliferation in a } \\
\text { dependent manner. The comparison } \\
\text { between effects of EVOO (A) and (B) } \\
\text { demonstrates significant powerful effects } \\
\text { of EVOO (A) respect to EVOO (B) } \\
p<0.0001\end{array}$ \\
\hline & & & & & In HEL cells: \\
\hline & $\begin{array}{l}\text { Zambonin, L. } \\
\text { [33] }\end{array}$ & 2012 & $\begin{array}{l}\text { Evaluation of the antioxidant activity of } \\
\text { phenolic acids in HEL cells }\end{array}$ & Proapoptotic effects in leukemia cells & $\begin{array}{ll}- & \text { Induce apoptosis } \\
- & \text { Increase caspases 3,8,9 activity } \\
- & \text { Increase ratio Bax/Bcl2 } \\
\text { - } & \text { Reduce Akt activation }\end{array}$ \\
\hline
\end{tabular}


Table 2. Cont.

\begin{tabular}{|c|c|c|c|c|c|}
\hline \multicolumn{6}{|c|}{ Extra Virgin Olive Oil } \\
\hline Type of Study & Reference & Year & Type of Intervention & Primary Outcome & $p$-Value for Primary Endpoint \\
\hline & $\begin{array}{l}\text { Incani, A. } \\
\text { [38] }\end{array}$ & 2016 & $\begin{array}{l}\text { Evaluation of two monovarietal EVOO } \\
\text { phenolic extracts (Bosana and Nera) on } \\
\text { Caco-2 cells }\end{array}$ & $\begin{array}{l}\text { Modulation of enterocyte response to } \\
\text { oxidative and inflammatory stimuli after } \\
\text { absorption of EVOO }\end{array}$ & $\begin{array}{l}\text { Protection of Caco-2 cell } \\
\text { monolayers against TBH and } \\
\text { oxysterols oxidative injury } \\
\text { ROS production inversely } \\
\text { correlated to decrease of } \\
\text { GSH levels } \\
\text { - Attenuation of TBH-induced } \\
\text { oxidative damage (Bosana type the } \\
\text { most active) }\end{array}$ \\
\hline Animal & $\begin{array}{l}\text { Priora, R. } \\
\text { [61] }\end{array}$ & 2008 & $\begin{array}{l}\text { Randomized study in } 6 \text { groups for } \\
\text { different treatments ( } 10 \text { rats x group). } \\
\text { They tested } 3 \text { types of oil characterized } \\
\text { by different MPC concentration: refined } \\
\text { olive oil with trace MPC (control), } \\
\text { low-MPC EVOO, and high-MPC EVOO }\end{array}$ & $\begin{array}{l}\text { Effect of EVOO in relation to MPC on } \\
\text { platelet aggregation and plasma } \\
\text { concentration of Hcy redox form }\end{array}$ & $\begin{array}{l}\text { - } \\
\text { agC of EVOO inhibits platelet } \\
\text { concentration of Hcy redox form }\end{array}$ \\
\hline \multirow{3}{*}{ Humans } & $\begin{array}{l}\text { Keys, A. } \\
{[16]}\end{array}$ & 1986 & $\begin{array}{l}\text { Study among } 15 \text { different cohorts } \\
(n=11.579 \text { healthy males) on mortality } \\
\text { from all causes, follow-up period } 15 \\
\text { years }\end{array}$ & $\begin{array}{l}\text { All cause and coronary disease death } \\
\text { during } 15 \text {-year follow-up was } \\
\text { significantly lower in cohorts with olive } \\
\text { oil as main fat }\end{array}$ & - N.A. \\
\hline & $\begin{array}{l}\text { De Lorgeril, } \mathrm{M} \text {. } \\
\text { [25] }\end{array}$ & 1994 & $\begin{array}{l}\text { MD alpha-linolenic acid rich } \\
\text { vs. } \\
\text { prudent diet in secondary prevention of } \\
\text { CHD patients }\end{array}$ & $\begin{array}{l}\text { Secondary prevention of coronary events } \\
\text { and deaths }\end{array}$ & $\begin{array}{ll}\text { - } & \text { Coronary events: } \\
\text { - } & \text { R.R. } 0.27(95 \% \text { CI, 0.12-0.59) } \\
\text { - } & p=0.001 \\
\text { - } & \text { Death: } \\
\text { - } & \text { R.R. } 0.30(95 \% \text { CI, 0.11-0.82) } \\
\text { - } & p=0.082\end{array}$ \\
\hline & $\begin{array}{l}\text { Visioli, F. } \\
\text { [35] }\end{array}$ & 2000 & $\begin{array}{l}\text { Six male volunteers } 50 \mathrm{~mL} \text { of olive oil } \\
\text { samples accompanied by } 40 \mathrm{~g} \text { of bread, } \\
\text { four times }\end{array}$ & $\begin{array}{l}\text { Olive oil phenolics are dose-dependently } \\
\text { absorbed in humans }\end{array}$ & - N.A. \\
\hline
\end{tabular}


Table 2. Cont.

\begin{tabular}{|c|c|c|c|c|c|}
\hline \multicolumn{6}{|c|}{ Extra Virgin Olive Oil } \\
\hline Type of Study & Reference & Year & Type of Intervention & Primary Outcome & $p$-Value for Primary Endpoint \\
\hline & $\begin{array}{l}\text { Riboli, E. } \\
{[68]}\end{array}$ & 2002 & $\begin{array}{l}\text { Multicenter prospective cohort study on } \\
521.000 \text { subjects investigation on the } \\
\text { relationship between nutrition and } \\
\text { cancer }\end{array}$ & $\begin{array}{l}\text { Evaluation of the possible correlation } \\
\text { between the incidence of cancer and } \\
\text { nutrition }\end{array}$ & $\begin{array}{l}\text { - Data collected indicates that the } \\
\text { MD is the most effective food } \\
\text { model in cancer prevention }\end{array}$ \\
\hline & $\begin{array}{l}\text { Salvini, S. } \\
\text { [42] }\end{array}$ & 2006 & $\begin{array}{l}\text { Randomized Cross over trial } 10 \\
\text { postmenopausal women about the effect } \\
\text { of high-phenol EVOO vs. low-phenol } \\
\text { EVOO on oxidative DNA damage }\end{array}$ & $\begin{array}{l}\text { Two types of olive oil were assumed for } 8 \\
\text { weeks ( } 50 \mathrm{~g} / \text { day) and were tested in } \\
\text { peripheral blood lymphocytes }\end{array}$ & $\begin{array}{l}\text { Oxidative DNA damage during } \\
\text { assumption of high-phenol EVOO } \\
\text { was } 30 \% \text { lower respect to mean } \\
\text { values observed during low-phenol } \\
\text { EVOO consumption }(p=0.02)\end{array}$ \\
\hline & $\begin{array}{l}\text { Covas, M.I. } \\
\text { [43] }\end{array}$ & 2006 & $\begin{array}{l}\text { Evaluated, in } 200 \text { healthy male } \\
\text { volunteers, the effects of polyphenol } \\
\text { content in olive oil on oxidative lipid } \\
\text { damage and plasma lipid levels }\end{array}$ & $\begin{array}{l}\text { Crossover study, enrolled subjects } \\
\text { assumed randomly } 3 \text { types of olive oils } \\
\text { daily administration }(25 \mathrm{~mL} / \text { day). } \\
\text { One type was low-phenols }(2.7 \mathrm{mg} / \mathrm{kg} \text { of } \\
\text { olive oil), medium-phenols }(164 \mathrm{mg} / \mathrm{kg}) \text {, } \\
\text { or high-phenols ( } 366 \mathrm{mg} / \mathrm{kg} \text { ) content. } \\
\text { Intervention periods were } 3 \text { weeks. }\end{array}$ & $\begin{array}{l}\text { - Values of oxidative stress } \\
\text { biomarkers were inversely related } \\
\text { to phenolic content }\end{array}$ \\
\hline & $\begin{array}{l}\text { Masala, G. } \\
{[72]}\end{array}$ & 2007 & $\begin{array}{l}\text { Evaluation of dietary patterns on overall } \\
\text { mortality in Italian elderly population } \\
\text { (aged }>60 \text { years) }\end{array}$ & $\begin{array}{l}\text { "Olive oil and salad" type is inversely } \\
\text { associated with all-cause mortality. } \\
\text { While the pasta and meat pattern have } \\
\text { an increased mortality for all causes. }\end{array}$ & 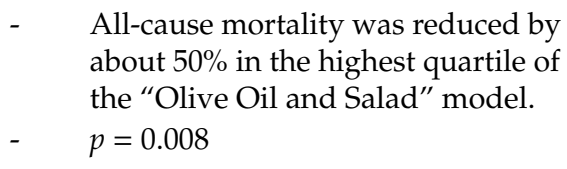 \\
\hline & $\begin{array}{l}\text { De Lorenzo, A. } \\
\text { [22] }\end{array}$ & 2010 & $\begin{array}{l}\text { IMD and IMOD vs. } \\
\text { usual diet in patients with CKD stage } \\
\text { II-III }\end{array}$ & $\begin{array}{l}\text { Effect of diet treatment on laboratory and } \\
\text { body composition parameters }\end{array}$ & $\begin{array}{ll}- & \text { Reduction of: } \\
- & \text { Hcy }(p=0.0116) \\
- & p(p<0.001) \\
- & \text { Microalbuminuria }(p=0.0086) \\
- & \text { hs-CRP }(p<0.05) \\
- & \text { FM }(\mathrm{kg}), \mathrm{FM}(\%),(p=<0.001)\end{array}$ \\
\hline
\end{tabular}


Table 2. Cont.

\begin{tabular}{|c|c|c|c|c|c|}
\hline \multicolumn{6}{|c|}{ Extra Virgin Olive Oil } \\
\hline Type of Study & Reference & Year & Type of Intervention & Primary Outcome & $p$-Value for Primary Endpoint \\
\hline & $\begin{array}{l}\text { Bendinelli, B. } \\
\text { [73] }\end{array}$ & 2011 & $\begin{array}{l}\text { Association between fruit, vegetable, } \\
\text { and olive oil consumption and the } \\
\text { incidence of CHD in Italian women }\end{array}$ & $\begin{array}{l}\text { 8-year follow-up in which the possible } \\
\text { relationships between dietary habits, } \\
\text { lifestyle, anthropometric measures, } \\
\text { and the development of CHD major } \\
\text { events were evaluated. }\end{array}$ & $\begin{array}{l}\text { Reverse association between } \\
\text { consumption of leafy vegetables } \\
\text { and olive oil and risk of } \\
\text { developing CHD. } \\
\text { Leaf vegetables: } \\
\text { H.R. } 0.54 \text { ( } 95 \% \text { CI } 0.33-0.90, p=0.03 \\
\text { Olive oil: } \\
\text { H.R. } 0.56 \text { ( } 95 \% \text { CI } 0.31-0.99, p=0.04 \text { ) }\end{array}$ \\
\hline & $\begin{array}{l}\text { Perez-Herrera, A. } \\
\text { [44] }\end{array}$ & 2012 & $\begin{array}{l}\text { Study randomized crossover of } 20 \text { obese } \\
\text { subjects that received four breakfasts } \\
\text { constituted by milk and muffin prepared } \\
\text { with one of four different oils: virgin } \\
\text { olive oil, sunflower oil, mixture seeds oil } \\
\text { with added dimethylpolyxiloxane, or } \\
\text { natural antioxidants from olive mill } \\
\text { wasterwater alperujo }\end{array}$ & $\begin{array}{l}\text { Evaluations of postprandial } \\
\text { inflammatory status in } 20 \text { obese subjects } \\
\text { by the activation of nuclear NF-kB, } \\
\text { the cytoplasmatic concentration of } \\
\text { NF-kB inhibitor, the mRNA levels of } \\
\text { NF-kB subunits and activators, } \\
\text { inflammatory molecules, and LPS levels }\end{array}$ & $\begin{array}{l}\text { - } \quad \text { Virgin olive oil and olive mill } \\
\text { wasterwater alperujo reduced } \\
\text { NF-kB activation, increased NF-kB } \\
\text { inhibitor, and decreased LPS } \\
\text { plasma concentration } \\
\text { - Seed oil increases mRNA } \\
\text { expression of NF-kB subunit, } \\
\text { inflammatory molecules, and LPS }\end{array}$ \\
\hline & $\begin{array}{l}\text { Di Daniele, N. } \\
\text { [23] }\end{array}$ & 2014 & $\begin{array}{l}\text { IMD and IMOD in patients with CKD } \\
\text { stage II-III vs. } \\
\text { low-protein diet } \\
\text { according to MTHFR genotypes }\end{array}$ & $\begin{array}{l}\text { Effect of diet treatment on laboratory and } \\
\text { body composition parameters }\end{array}$ & $\begin{array}{l}\text { Reduction of Hcy in T } \\
\text { (+) genotypes: -IMD: } 3.08 \mathrm{~mol} / \mathrm{L} \\
\text { 95\% CI, } 4.94-1.23), p=0.001 \\
\text {-IMOD: } 9.18 \mathrm{~mol} / \mathrm{L}, 95 \% \mathrm{CI} \\
\text { 11.04-7.33), } p<0.001\end{array}$ \\
\hline
\end{tabular}


Table 2. Cont.

\begin{tabular}{|c|c|c|c|c|c|}
\hline \multicolumn{6}{|c|}{ Extra Virgin Olive Oil } \\
\hline Type of Study & Reference & Year & Type of Intervention & Primary Outcome & $p$-Value for Primary Endpoint \\
\hline & $\begin{array}{l}\text { Agrawal, K. } \\
\text { [60] }\end{array}$ & 2017 & $\begin{array}{l}\text { Double-blind, randomized controlled } \\
\text { crossover study on } 9 \text { healthy subjects. } \\
\text { They assumed } 40 \mathrm{~mL} / \text { week of tree } \\
\text { different phenolic content EVOO. }\end{array}$ & $\begin{array}{l}\text { Evaluation of EVOO assumption on } \\
\text { inhibition of platelet aggregation pre and } \\
2 \mathrm{~h} \text { post-EVOO intake }\end{array}$ & $\begin{array}{l}\text { Decline of Pmax is related to } \\
\text { oleocanthal intake }(r=0.56 \\
p=0.002)\end{array}$ \\
\hline & $\begin{array}{l}\text { Estruch, R. } \\
\text { [24] }\end{array}$ & 2018 & $\begin{array}{l}\text { Mediterranean Diet supplements with } \\
\text { EVOO or nuts vs. reduced-fat diet in } \\
7447 \text { Spanish subjects }\end{array}$ & Major CV events & $\begin{array}{ll}- & \text { MD+EVOO } \\
- & \text { H. R. } 0.69(95 \% \text { CI, 0.53-0.91) } \\
- & \text { MD+NUTS } \\
- & \text { H.R. } 0.72(95 \% \text { CI, 0.54-0.95) }\end{array}$ \\
\hline
\end{tabular}

Akt, protein kinase B; ATM, ataxia-telangectasia mutated; Bax, (Bcl-2)-associated X protein; Bcl-2, B-cell lymphoma protein 2; Caco-2, heterogeneous human epithelial colorectal adenocarcinoma cell lines; CHD, coronary heart disease; CKD, chronic kidney disease; COX-1, cyclooxygenase-1; COX-2, cyclooxygenase-2; CV, cardiovascular; EVOO, extra virgin olive oil; FASN, inhibitors of fatty acid synthase; FM, fat mass; GSH, glutathione; Hcy, homocysteine; HEL, human erythroleukemia cell lines; HER2, receptor tyrosine-protein kinase erbB-2; hs-CRP, high sensitivity-C reactive protein; HT, hydroxytyrosol; HUVEC, human umbilical vein endothelial cell lines; HVA, homovanillyl alcohol; ICAM-1, intercellular adhesion molecule 1; IMD, Italian Mediterranean diet; IMOD, Italian Mediterranean organic diet; LDL, low-density lipoprotein; LPS, lipopolysaccharide; MD, Mediterranean diet; MDM, monocytes-derived macrophages; MPC-OOE, minor polar compounds olive oil extract; MPC, minor polar compounds; MTHFR, methylene tetrahydrofolate reductase; NF-kB, nuclear factor kappa-light-chain-enhancer of activated B cells; OleA, oleuropein aglycone; P, phosphorus; Pmax, maximum platelet aggregation; ROS, reactive oxygen species; SKBR3, human breast cancer cell lines; TBH, tert-butyl hydroperoxide; VCAM-1, vascular cell adhesion molecule 1; VOO, virgin olive oil. 
Prieto et al. [80] investigated, in Swiss Webster mice, the effects (on hormonal, physiological, and metabolic parameters) of a diet having EVOO as the main source of fat, compared to a diet enriched with butter. Moreover, the authors analyzed fecal DNA e $16 \mathrm{~S}$ rRNA genes. In the mice with butter diets, there were higher values of systolic blood pressure and a greater percentage of Desulfovibrio sequences compared to the mice on EVOO diet. In addition, in mice with EVOO diet, the authors observed reduced plasma levels of insulin and leptin. The concentration of leptin was inversely related to Sutterellaceae, Marispirillum, and Mucilaginibacter dageonensis. Therefore, the intake of EVOO would seem to influence the composition of the intestinal microbiota, which in turn can positively affect health status.

In spontaneous hypertension rats, M. Hidalgo et al. [81] investigated the effects of EVOO on gut microbiota composition and blood pressure levels. After 12 weeks, the rats fed with the diet enriched with EVOO had significant difference in Lactobacillus and Clostridia XIV percentage with respect to rats fed with a standard diet. Moreover, the abundance of Clostridia XIV was inversely related to systolic blood pressure values.

In a randomized, double blind cross-over human study [82] conducted on 10 hypercholesterolemic subjects, the authors evaluated the effects of the consumption of $25 \mathrm{~mL} /$ day of olive oil for three weeks on human intestinal immune function. The authors studied the effects of three olive oils (OO) differing in their content of phenolic compounds: $\mathrm{OO}$ varieties containing $80 \mathrm{mg}$ phenolic compounds $/ \mathrm{kg}$, $\mathrm{OO}$ containing $500 \mathrm{mg}$ phenolic compounds $/ \mathrm{kg}$ from OO and OO containing a mixture of $500 \mathrm{mg} \mathrm{PC} / \mathrm{kg}$ from $\mathrm{OO}$ and thyme. The authors concluded that the consumption of olive oil with a high content of phenolic compounds induces an increased stimulation of the intestinal immune system.

\section{Health Effects of Phenolic Compounds Present in Olea By-Products and Waste}

Olea by-products and waste are precious sources of bioactive compounds that could be selectively recovered and reused for industrial applications. These principles are the pillars of the circular economy, a model of economy where by-products are not waste but resources to be valorized and reused (Figure 3).

The material balance of the process is equal to a total of 73,200 $\mathrm{kg}$ as input and output, of which $2,940 \mathrm{~kg}$ are the main outputs. It should be noted how this multifunctional platform is highly innovative and in line with circular economy principles. Each residue of the process (water, olive stones, destoned pulp) would come into new use in the same and/or external processes, according to the "zero waste" model. Indeed, after the extraction of the bioactive fractions, residues of the olive oil mill can be used as animal feed, compost, or other agricultural or agro-industrial products and/or be exploited as energy sources in the same biorefinery or sold for other economic activities.

Olive tree cultivation is particularly widespread in the Mediterranean Basin and provides a strong contribution as a source of polyphenols. After the production of olive oil, olive pulp and olive oil wastewaters are obtained as by-products in large quantities, representing a great environmental problem in consideration of their high toxicity [83]. Olive oil by-products such as olive mill and leaves are allowed for production of feed, cosmetics, food, and nutraceuticals, whereas waste and olive oil waste waters are only allowed for use in agronomy. The importance and use of waste from the production of oil, as a resource and source of polyphenols, has been described by Cecchi et al. in a recent study [84], which showed that only $0.5 \%$ of the total polyphenols present in olives is found in the extracted oil, while the remainder is waste that can be used for the formulation of supplements for the nutraceutical sector.

Regarding the recovery of waste from oil production, there are studies in literature concerning the treatment of wastewater. A recent study demonstrated that the retentates obtained after microfiltration, ultrafiltration, nanofiltration, and reverse osmosis are stable; HT recovered was stable for 24 months and the process showed a good reproducibility [85].

Among the wastes from oil production, in addition to olive mill wastewaters, there is patè, a particular dried olive pomace containing high amounts of HT and OLE. It has been estimated that $1.0 \mathrm{~g}$ 
of patè contains the same amount of polyphenols as $200 \mathrm{~g}$ of EVOO, thus representing a good source to be used for industrial applications [86]. A recent study indicated that extracts obtained from olive mill wastewater exhibited cytoprotective effects in PC12 cells [87]. Similarly, they showed antibacterial activity [88].

HT is a small phenol that can be recovered from olive oil by-products and used as starting materials for the preparation of novel bioactive compounds [89-92]. Thanks to the presence of the alcoholic group, it is possible to prepare the corresponding alkyl derivatives showing better lipophilicity and bioavailability than HT. Figure 5 describes some examples of saturated and unsaturated lipophilic HT derivatives. These compounds could be obtained by a selective esterification of HT with acyl chlorides of different chain length in order to modulate their lipophilicity $[89,93]$. Interestingly, the same functionalization has been introduced in Olea europaea L. extracts enriched in HT recovered by olive oil by-products, and their antiproliferative activity on the human colon cancer cell line HCT8- $\beta 8$ was evaluated [7]. The experimental results indicated that both the presence and the length of the alkyl chain exert a relevant role on the antiproliferative activity [94]. In a similar manner, HT stearate and HT oleate showed anti-inflammatory activity [95]. To date, it appears that experiments on animal and human models are lacking (Table 3) [96].<smiles>CCCC(=O)OCCc1ccc(O)c(O)c1</smiles>

Hydroxytyrosol butanoate<smiles>CCCCCCCC(=O)OCCc1ccc(O)c(O)c1</smiles>

Hydroxytyrosol octaonoate<smiles>CCCCCCCCCCCCCCCCCC(=O)OCCc1ccc(O)c(O)c1</smiles>

Hydroxytyrosol stearate<smiles>CCCCCCCC/C=C/CCCCCCCC(=O)OCCc1ccc(O)c(O)c1</smiles>

Hydroxytyrosol oleate

Figure 5. Lipophilic HT derivatives. 
Table 3. Biological activity of Olea europaea L. by-products.

\begin{tabular}{|c|c|c|c|c|c|}
\hline \multicolumn{6}{|c|}{ By-Products of EVOO Process } \\
\hline Type of Study & Reference & Year & Type of Intervention & Primary Outcome & $p$-Value for Primary Endpoint \\
\hline \multirow{4}{*}{ In vitro cell models } & $\begin{array}{l}\text { Obied, H.K. } \\
{[88]}\end{array}$ & 2007 & $\begin{array}{l}\text { Olive mill waste waters tested against } \\
\text { Staphylococcus aureus, Bacillus subtilis, } \\
\text { Escherichia coli, Pseudomonas aeruginosa, } \\
\text { Candida albicans, Aspergillus niger. }\end{array}$ & $\begin{array}{l}\text { Antibacterial activity } \\
\text { against } S \text {. aureus, } B . \\
\text { subtilis, } E \text {. coli, and } P \text {. } \\
\text { aeruginosa }\end{array}$ & $\begin{array}{l}\text { At lower concentrations, the extracts } \\
\text { exhibited differential antibacterial action, } \\
\text { but at } 5 \mathrm{mg} \text { /disc extracts were active } \\
\text { against all the challenge bacteria }\end{array}$ \\
\hline & $\begin{array}{l}\text { Schaffer, S. } \\
{[87]}\end{array}$ & 2010 & $\begin{array}{l}\text { OMWW extracts and HT were evaluated } \\
\text { for their cytoprotective effects in an } \\
\text { in vitro model of neuronal-like PC12 cells }\end{array}$ & $\begin{array}{l}\text { Cytoprotective effects in } \\
\text { PC12 cells subjected to } \\
\text { oxidative or nitrosative } \\
\text { stress by adding either } \\
\text { ferrous iron or sodium } \\
\text { nitroprusside to the cell } \\
\text { culture medium for } 18 \mathrm{~h}\end{array}$ & $\begin{array}{l}\text { Incubating PC12 cells with wastewater } \\
\text { extract protect from nitrosative stress. } \\
\text { The extract was able to maintain ATP } \\
\text { levels but not MMP. }\end{array}$ \\
\hline & $\begin{array}{l}\text { Bernini, R. } \\
\text { [93] }\end{array}$ & 2017 & $\begin{array}{l}\text { Lipophilic fractions from Olea } \\
\text { by-products were tested on human colon } \\
\text { cancer cell line HCT8- } \beta 8 \text { engineered to } \\
\text { overexpress estrogen receptor } \beta \text { (ER } \beta \text { ) }\end{array}$ & Antiproliferative effect & $\begin{array}{l}\text { HT and lipophilic fractions significantly } \\
\text { reduced the proliferation of } \\
\text { HCT8- } \beta 8 \text {-expressing cells in a } \\
\text { concentration-dependent manner. } \\
\text { HT oleate showed the greater effect. }\end{array}$ \\
\hline & $\begin{array}{l}\text { Plastina, P. } \\
\text { [95] }\end{array}$ & 2019 & $\begin{array}{l}\text { Phenolic extracts from OMWW were } \\
\text { tested for their ability to reduce NO } \\
\text { production by LPS-stimulated } \\
\text { RAW-264.7 macrophages }\end{array}$ & $\begin{array}{l}\text { Anti-inflammatory } \\
\text { activity }\end{array}$ & $\begin{array}{l}\text { HT stearate and HT oleate decrease NO } \\
\text { production in a concentration-dependent } \\
\text { manner }\end{array}$ \\
\hline Humans & $\begin{array}{l}\text { Visioli, F. } \\
\text { [96] }\end{array}$ & 2009 & $\begin{array}{l}\text { OMWW extracts were tested on human } \\
\text { volunteers } 1 \mathrm{~h} \text { after ingestion }\end{array}$ & $\begin{array}{l}\text { Plasma antioxidant } \\
\text { capacity and total reduced } \\
\text { glutathione }\end{array}$ & $\begin{array}{l}\text { No difference in plasma antioxidant } \\
\text { capacity; a significant increase in total } \\
\text { plasma glutathione concentration }\end{array}$ \\
\hline
\end{tabular}

ATP, adenosine triphosphate; ER $\beta$, estrogen receptor beta; HT, hydroxytyrosol; LPS, lipopolysaccharide; MMP, mitochondrial membrane potential; NO, nitric oxide; OMWW, olive mill wastewater; RAW-264.7, Abelson murine leukemia virus transformed. 


\section{Health Effects of Phenolic Compounds Present in Olea Leaf and Olea Leaf Extracts}

Olive leaves, deriving both from the processing of olives and from pruning practices, can be definitely considered a waste of the olive supply chain. These vegetal tissues are a valuable source of bioactive compounds including phenols with low molecular weight [97]. In olive leaf, the prominent constituent is the secoiridoid OLE, which by enzymatic or chemical hydrolysis produces the aglyconic form present in the oil, HT, elenolic acid, and glucose [6,49].

In a 2016 study, several extracts from olive leaf were analyzed. Qualitative differences in total polyphenols and in OLE content were found. In particular, polyphenols varied from 7.87 to $34.21 \mathrm{mg} / \mathrm{g}$, while OLE varied from 2.79 to $21.03 \mathrm{mg} / \mathrm{g}$ depending on the kind of leaf (fresh, refrigerated, dried, frozen, or lyophilized), cultivar, sampling time, and production area. This study has pointed out that OLE and stability are related to the extraction temperature and drying process [7].

Many benefits are related to the properties and chemical characteristics of olive leaf. For this reason, many studies are focused on the use of olive leaf for human consumption. In the last few years, olive leaf extracts have been used by the food industry as foodstuffs or food additives [98] producing functional foods with health properties. In a 2017 review, all the studies carried out on the benefits of olive leaves and their extracts were collected [99]. To date, olive leaf extracts have been sold as dried leaves, powders, extracts, or tablets used as herbal teas or food supplements, available all over the world. Extracts of hot fresh water leaves are eaten to increase diuresis and treat hypertension and bronchial asthma [99]. Olive leaves also affect metabolism, so they have been used as a traditional herbal medicine for years. Many studies, both in vitro and in vivo, demonstrated their important biological properties, including radio-protective, anti-proliferative, and cytotoxic effects on cancer cells; anti-fungal activity; and anti-atherosclerotic, hypoglycemic, and cardioprotective effects [99]. As reported above, the olive leaves antioxidant activity is ascribed to secondary metabolites, in particular OLE and its ability to chelate $\mathrm{Cu}$ and Fe metal ions, which catalyze free radical generation reactions [100]. Janahmadi et al. [101] showed that OLE intake in rats with a permanent ligation of left main coronary attenuated heart failure progression through antioxidative and anti-inflammatory effects. In alloxan-diabetic rats, the intake of olive leaf extract in a concentration of $16 \mathrm{mg} / \mathrm{kg}$ body weight influences their lipid profile, improving hypercholesterolemia associated with hyperglycemia [102]. A recent study reported that 20 healthy subjects after an intake of $20 \mathrm{mg}$ of OLE before lunch showed an improved post prandial glycemic profile by reducing glucose and increasing insulin and GPL-1 [103]. In overweight middle-aged men at risk of developing diabetes, supplementation with olive leaf polyphenols for 12 weeks significantly improved insulin sensitivity and pancreatic $\beta$-cell secretory capacity [104].

What is of translational importance is that OLE was found to be a powerful sensitizer of doxorubicin (DXR)-mediated killing of prostate and breast cancer cells. In fact, in a first study, $200 \mu \mathrm{g} / \mathrm{mL}$ of OLE, was able to inhibit cell proliferation at very low doses of DXR (3-12.5 nM). In a second study in a breast tumor xenograft in mice, the intraperitoneal injection of the combination of $1.5 \mathrm{mg} / \mathrm{kg}$ of, followed by $50 \mathrm{mg} / \mathrm{kg}$ of OLE, decreased the volume of the tumor threefold [105,106]. A recent investigation demonstrated that olive-leaf ingredients, such as HT, are good antioxidants for food lipids even at very low doses $\left(<100 \mathrm{mg} \mathrm{kg}^{-1}\right)$, without cytotoxic effects, nor do they inhibit probiotic lactating producing bacteria.

Furthermore, olive leaf-derived phenolic compounds have shown significant antimicrobial properties, thus playing an important role in the control of food processing and preservation during storage, as well as in counteracting pathological microorganisms like Helicobacter pylori and other food-borne pathogens [107]. As a consequence of their recognized nutraceutical activities, olive-leaf extracts containing polyphenols can be used as foodstuff ingredients. OLE, and in particular its aglycone obtained by enzymatic hydrolysis of pure extracts from olive leaves, as previously reported [108], also showed an anti-amyloid effect, resulting in protection against the cytotoxic effects of amyloid aggregates [109,110], as well as having an autophagy inducer effect by modulating the AMPK/mTOR pathway and by activating autophagy gene expression mediated through sirtuins or EB transcription factor $[108,111,112]$. These last actions suggest that OLE aglycone may have a neuroprotective action 
in diseases such as Alzheimer's, characterized by amyloid deposition and autophagy impairment, contributing to a decrease in aggregated protein and to a reduction in cognitive impairment in in vivo models [113]. Another interesting effect of OLE aglycone is its modulation in the tumor microenvironment to control tumor angiogenesis as reported by Margheri et al. in 2019 [114]. They showed that the treatment with OLE aglycone of "senescence-associated-secretory-phenotype" (SASP) fibroblasts, an accepted cellular senescence model decreased the release of SASP pro-angiogenic factors in cell media, inhibited dependent cell invasion, and inhibited formation of capillary-like structures of endothelial cells exposed to the same media, suggesting a mechanistic interpretation of the anti-angiogenic activities for cancer prevention by olive oil polyphenols.

Moreover, as recently reported in a review that summarized the existing in vitro and in vivo studies [115] on OLE and its metabolite HT [116], these compounds not only exert a chemopreventive action "per se" (by increasing apoptosis and decreasing proliferation and viability), but they may also be used as adjuvants to conventional antitumoral therapies $[117,118]$. OLE, at non-toxic doses, blocks the AKT pathway and may act synergistically with several current chemotherapies used against BRAF melanoma cells, allowing a decrease in drug dosage that can lower the adverse effects on non-target cells and reverse resistance towards conventional agents such as 42-O-(2-hydroxyethyl) rapamycin (RAD001) and dacarbazine (DTIC).

In the context of anticancer therapy, the anthracycline DXR has a limited use as a chemotherapeutic agent due to its cardio-toxic effects. Consequently, sustained research has been focused on identifying effective drugs and strategies in order to reduce DXR toxicity without compromising its antitumor efficacy. Some studies reported that OLE prevented cardiomyopathy caused by chronic DXR toxicity and, by attenuating inflammatory development and the degenerative myocardial lesions, preserved left ventricle contractility and/or [119] acted as a sensitizer of DXD-induced death of cancer cells.

In addition, [118] reported that leaf extract enriched in OLE was even more effective than OLE alone against melanoma cells, probably because of the co-presence of other polyphenols, suggesting that the combination of several components (rather than any single one alone) might be the ultimate chemopreventive agent (Table 4). 
Table 4. Biological activity olive leaf extracts.

\begin{tabular}{|c|c|c|c|c|c|}
\hline \multicolumn{6}{|c|}{ Olive Leaf Extracts } \\
\hline Type of Study & Reference & Year & Type of Intervention & Primary Outcome & $p$-Value for Primary Endpoint \\
\hline \multirow{8}{*}{ In vitro cell models } & $\begin{array}{l}\text { Andrikopoulos, } \\
\text { N.K. } \\
{[100]}\end{array}$ & 2002 & $\begin{array}{l}\text { Effects against copper ion-induced } \\
\text { low-density lipoprotein (LDL) oxidation }\end{array}$ & LDL mean protection activity & $\begin{array}{l}\text { Quercetin, luteolin, and rutin, activities } \\
46.8 \%, 49.5 \% \text {, and } 53.7 \% \mathrm{MP} \text {, respectively, } \\
\text { comparable to oleuropein the } 49.0 \% \mathrm{MP}\end{array}$ \\
\hline & $\begin{array}{l}\text { Sudjana, A.N. } \\
\text { [107] }\end{array}$ & 2009 & Antimicrobical activity & $\begin{array}{l}\text { Role in regulating the composition of the } \\
\text { gastric flora }\end{array}$ & $\begin{array}{l}\text { Specific activity, in reducing levels of } H \text {. } \\
\text { pylori and } C \text {. jejuni. }\end{array}$ \\
\hline & $\begin{array}{l}\text { Rigacci, S. } \\
{[109,110]}\end{array}$ & $\begin{array}{l}2010 \\
2011\end{array}$ & $\begin{array}{l}\text { Effects on amylin and peptide } \\
\text { aggregation and cytotoxicity }\end{array}$ & $\begin{array}{l}\text { Hindering amylin and } \mathrm{A} \beta \text {-peptide } \\
\text { aggregation, preventing their } \\
\text { cytotoxicity }\end{array}$ & $\begin{array}{l}\text { Increased viability of } \beta \text {-pancreatic and } \\
\text { neuroblastoma cells decreasing caspase- } 3 \\
\text { activity }\end{array}$ \\
\hline & $\begin{array}{l}\text { Rigacci, S. } \\
\text { [111] }\end{array}$ & 2015 & Neuroprotection effect & $\begin{array}{l}\text { Autophagy induction both in vitro in } \\
\text { neuronal cells and in in vivo } \mathrm{A} \beta \text { model } \\
\text { deposition (TgCRND } 8 \text { mice) by } \\
\mathrm{Ca} 2+/ \mathrm{CaMKK} \beta / \mathrm{AMPK} / \mathrm{mTOR} \text { axis }\end{array}$ & $\begin{array}{l}\text { Cytosolic } \mathrm{Ca}^{2+} \text { increase activates } \\
\text { CaMKK } \beta \text { and pAMPK concomitant with } \\
\text { increased beclin1/LC3II and decreased } \\
\text { phospho-mTOR and phospho-p70S6K } \\
\text { expression }\end{array}$ \\
\hline & $\begin{array}{l}\text { Papachristodoul } \\
\text { A. } \\
\text { [105] }\end{array}$ & 2016 & $\begin{array}{l}\text { Anticancer effect and adjuvant to } \\
\text { antitumoral therapies }\end{array}$ & $\begin{array}{l}\text { Lowering of the cytotoxic dose in } \\
\text { doxorubicin to obtain the same } \\
\text { antiproliferative effect in prostate cancer }\end{array}$ & $\begin{array}{l}\text { Remarkable induction of autophagy } \\
\text { correlated to significant metabolite } \\
\text { alterations }\end{array}$ \\
\hline & $\begin{array}{l}\text { Luccarini, I. } \\
\text { [112] }\end{array}$ & 2016 & Neuroprotection effect & $\begin{array}{l}\text { Counteracting neuronal damage through } \\
\text { modulation of the PARP1-SIRT1 } \\
\text { interplay both in neuronal cells and in } \\
\text { TgCRND8 mice }\end{array}$ & $\begin{array}{l}\text { In vitro reduction of PARP1 activation } \\
\text { and paralleled overexpression of Sirtuin1 } 1 \\
\text { In vivo, (in addition to above reported } \\
\text { effects), a decrease of NF-kB and of the } \\
\text { pro-apoptotic marker p53 expression }\end{array}$ \\
\hline & $\begin{array}{l}\text { Miceli, C. } \\
\text { [108] }\end{array}$ & 2018 & Cardioprotective effect & $\begin{array}{l}\text { Cardioprotection on MAO-A } \\
\text { overexpressed cardiomyocytes by } \\
\text { restoring the defective autophagic flux } \\
\text { due to oxidative stress }\end{array}$ & $\begin{array}{l}\text { Reduction of MAO-induced } \\
\text { cardiotoxicity through MTT. } \\
\text { Autophagy induction by TFEB nuclear } \\
\text { translocation. }\end{array}$ \\
\hline & $\begin{array}{l}\text { Ruzzolini, J. } \\
{[118]}\end{array}$ & 2018 & $\begin{array}{l}\text { Anticancer effect and adjuvant to } \\
\text { antitumoral therapies }\end{array}$ & $\begin{array}{l}\text { Reduction of viability of BRAF } \\
\text { melanoma cells. Enhanced effects with } \\
\text { chemotherapic drugs (dacarbazina and } \\
\text { everolimus) at no toxic dose. }\end{array}$ & $\begin{array}{l}\text { High dose induced cell death by } \\
\text { apoptosis, while no toxic dose affected } \\
\text { viability through the inhibition of } \\
\text { phosphorylation of AKT and the S6 } \\
\text { pathway }\end{array}$ \\
\hline
\end{tabular}


Table 4. Cont.

\begin{tabular}{|c|c|c|c|c|c|}
\hline \multicolumn{6}{|c|}{ Olive Leaf Extracts } \\
\hline Type of Study & Reference & Year & Type of Intervention & Primary Outcome & $p$-Value for Primary Endpoint \\
\hline & $\begin{array}{l}\text { Margheri, } \\
\text { F.M.B. } \\
\text { [114] }\end{array}$ & 2019 & Effect on tumor microenvironment & $\begin{array}{l}\text { Anti-angiogenic activity in } \\
\text { senescence-associated-secretory-phenotype } \\
\text { (SASP) fibroblast cultured media }\end{array}$ & $\begin{array}{l}\text { Decrease of pro-angiogenic factors } \\
\text { release in SASP fibroblasts cultured } \\
\text { media and inhibition of cell-dependent } \\
\text { invasion and of capillary-like structure } \\
\text { formation of endothelial cells exposed to } \\
\text { the above media }\end{array}$ \\
\hline \multirow{5}{*}{ Animals } & $\begin{array}{l}\text { Jemai, H. } \\
\text { [102] }\end{array}$ & 2009 & Effects in alloxan-diabetic rats & Hypoglycemic and antioxidant activity & \\
\hline & $\begin{array}{l}\text { Andreadou, I. } \\
\text { [119] }\end{array}$ & 2014 & $\begin{array}{l}\text { Effect on chronic doxorubicin induced } \\
\text { cardiomyopathy }\end{array}$ & $\begin{array}{l}\text { Prevention of the structural, functional, } \\
\text { and histopathological cardiac effects }\end{array}$ & $\begin{array}{l}\text { Activation of AMPK and suppression of } \\
\text { iNOS. } \\
\text { Reduction of pro-apoptotic mediators } \\
\text { and modulation of myocardial } \\
\text { metabolism. }\end{array}$ \\
\hline & $\begin{array}{l}\text { Rigacci, S. } \\
{[111]}\end{array}$ & 2015 & See above & & \\
\hline & $\begin{array}{l}\text { Luccarini, I. } \\
\text { [112] }\end{array}$ & 2016 & See above & & \\
\hline & $\begin{array}{l}\text { Janahmadi, Z. } \\
\text { [101] }\end{array}$ & 2017 & $\begin{array}{l}\text { Cardioprotection in rats with heart } \\
\text { failure }\end{array}$ & $\begin{array}{l}\text { Antioxidative and } \\
\text { anti-inflammatory effects }\end{array}$ & $\begin{array}{l}\text { Increase of SV, EF, FS, and CO }(p<0.05) \text {, } \\
\text { serum SOD and GRx. } \\
\text { Reduction of serum MDA, IL- } 1 \beta \text { or } \\
\text { TNF- } \alpha(p<0.05) \text {. }\end{array}$ \\
\hline \multirow[t]{2}{*}{ Humans } & $\begin{array}{l}\text { De Bock, M. } \\
{[104]}\end{array}$ & 2013 & $\begin{array}{l}46 \text { Participants (aged } 46.465 .5 \text { years and } \\
\text { BMI } 28.062 .0 \mathrm{~kg} / \mathrm{m}^{2} \text { ) were randomized to } \\
\text { receive capsules with olive leaf extract } \\
\text { (OLE) or placebo for } 12 \text { weeks }\end{array}$ & $\begin{array}{l}\text { Improvement in insulin sensitivity and } \\
\beta \text {-pancreatic cell secretory capacity }\end{array}$ & $\begin{array}{l}\text { Insulin sensitivity }(p=0.024) \\
\beta \text {-pancreatic cell responsiveness } \\
(p=0.013)\end{array}$ \\
\hline & $\begin{array}{l}\text { Carnevale, R. } \\
\text { [103] }\end{array}$ & 2018 & $\begin{array}{l}\text { Twenty healthy subjects were } \\
\text { randomized to receive } 20 \mathrm{mg} \text { oleuropein } \\
\text { or } 20 \mathrm{mg} \text { placebo before lunch }\end{array}$ & $\begin{array}{l}\text { Improvement in postprandial } \\
\text { glycemic profile }\end{array}$ & $\begin{array}{l}\text { Lower blood glucose, DPP-4 activity, } \\
\text { and higher insulin and glucagon-like } \\
\text { peptide-1 vs. placebo }\end{array}$ \\
\hline
\end{tabular}

AKT, protein kinase B; AMPK, $5^{\prime}$ adenosine monophosphate-activated protein kinase; BMI, body mass index; BRAF, B-Raf proto-oncogene; CaMKK $\beta$, Ca2+/calmodulin-dependent protein kinase kinase $\beta ; C O$, cardiac output; DPP-4, dipeptidyl peptidase-4; EF, ejection fraction; FS, fractional shortening; GRx, glutathione reductase; HT, Hydroxytyrosol; IL-1 $\beta$, interleukin-1 $\beta$; iNOS, nitric oxide inducible isoform; LDL, low-density lipoprotein; MAO-A, monoamine oxidase A; MDA, malondialdehyde; MP, mean protection; mTOR, mammalian target of rapamycin; MTT assay, 3-(4,5-dimethylthiazol-2-yl)-2,5-diphenyltetrazolium bromide; NF-KB, nuclear factor kappa-light-chain-enhancer of activated B cells; OLE, oleuropein ORAC, oxygen radical absorbance capacity; PARP1, poly[ADP-ribose] polymerase 1; SASP, senescence associated secretory phenotype; SIRT1, NAD-dependent deacetylase sirtuin-1; SV, stroke volume; TEAC, Trolox equivalent antioxidant capacity; TFEB, transcription factor EB; TNF- $\alpha$, tumor necrosis factor- $\alpha$. 


\section{Bioaccessibility and Bioavailability of Olea Minor Compounds}

Among the minor polar compounds of Olea products HT, Tyr, and OLE have different bioaccessibility and bioavailability. One of the first studies on the bioavailability of the minor polar compounds was conducted by Visioli et al. from 2000, which showed that HT and Tyr are dose-dependently absorbed [35]. In a recent review, studies on the bioavailability of principal Olea minor compounds-such as HT, Tyr, and OLE—in olive oil were collected [120]. In a 2016 study, the plasma levels of HT were evaluated after ingestion of olive oil and EVOO. The pharmacokinetic results show that it was not possible to detect HT in the blood after the ingestion of ordinary olive oil, unlike the results obtained after the ingestion of EVOO [121].

As many authors reported, the bioaccessibility regards the amount of component(s) of interest that is (are) released from the food matrix into the gastrointestinal (GI) tract, whereas the bioavailability is the quantity of the same digested compound(s) that is(are) absorbed and metabolized within the human body. As for OLE, some authors reported that, under in vitro gastrointestinal conditions, it was the most resistant compound among those present in olive leaves, varying its content between $26 \%$ and $61 \%$, depending on the type of extract during the first hour [122]. The same authors found that the intestinal phase affected OLE more than the gastric one probably due to pancreatic enzymatic activity and alkaline $\mathrm{pH}$ contributing to a reduction of its bioaccessibility, so that at the end of the digestion processes only $10 \%$ of OLE was present.

HT and OLE bioaccessibility has been investigated in vitro by Jilani $\mathrm{H}$ et al. [123] in relationship to the potential use of Saccharomyces cerevisiae as a new carrier of OLE as means to protect their lasting antioxidant capacity during simulated gastrointestinal digestion.

Using an in vivo digestion condition, de Bock et al. [124] found that after ingestion of different doses of OLE and HT in capsule or liquid form, the plasma of subjects receiving liquid doses $(2.74 \mathrm{ng} / \mathrm{mL})$ showed detectable peak concentrations that were higher compared to those who consumed capsules $(0.47 \mathrm{ng} / \mathrm{mL})$. In fact, previous results showed the influence of the dose and formulation taken by the subjects, in addition to gender, in plasma concentrations. In the same study, the authors also noticed that the primary metabolites identified in urine and plasma were the conjugated metabolites of HT, mainly consisting of HT sulphated and glucuronidated compounds [125]. The gut microbiota is another factor that may influence the bioavailability and bioaccessibility of olive phenolic compounds by performing biotransformation to other active metabolites with interesting beneficial health properties in bowel diseases [126]. Using human fecal microbiota, an in vitro model [127] observed that OLE was rapidly deglycosylated until $6 \mathrm{~h}$ of incubation producing oleuropein OLE aglycone, that, on the other hand, was degradated into elenolic acid and HT by microbial esterase activity, until it disappeared after $48 \mathrm{~h}$. On the contrary, HT, the main metabolite of OLE ester hydrolysis constantly increased during the same fermentation period. The same authors combined the in vitro colon fermentation studies with an in vivo intervention and found, after 3 weeks' intake of phenol-rich olive oil, a significant increase in the concentration of free HT in the feces of the all participants in the study, confirming the in vitro findings.

Interestingly, Santos et al. [128] showed that conversion of OLE into HT was performed by lactic acid bacteria, in particular by Lactobacillus plantarum, and on the basis of this evidence, some authors recently developed oral granules for co-delivery of L. plantarum and a standardized olive leaf extract (Phenolea ${ }^{\circledR}$ Active F) in order to foster OLE metabolism and provide high levels of HT [129].

\section{Conclusions}

Olea europaea L. fruits and leaves are a matrix rich in bioactive compounds such as unsaturated acids, phenolics, phytosterols, tocopherols, and squalene. The main components are fatty acids, in particular oleic and linoleic acids, while secoiridoids, polyphenols, phenols, and lignans turned out to be minor polar compounds. HT and OLE are the most active compounds; HT is present mainly in fruits, olive oil, and olive oil by-products, while OLE is present in Olea leaves. Despite their low concentration, they are responsible for numerous health effects in humans. The chemical characteristics, 
functional or medical food properties, biological and biomedical activities of these compounds were described in this review with the aim to demonstrate how the olive tree can be a food species of great scientific and health interest.

EVOO is a functional food with legal health claims, certified as cardioprotective. These characteristics are related to the content of minor polar compounds, in particular to HT and its various derivatives. Therefore, among all dietary plans, a MD based on the daily consumption of EVOO as a source of fat, is an ideal dietary model for its beneficial cardioprotective effects, longevity, and prevention of NCDs.

Recent circular economy models promoting green technologies for the recovery of active compounds from by-products and waste are already operational in the olive-oil industry. Biological and biomedical activities of many secondary metabolites from Olea europaea L. have been scientifically demonstrated. Studies on the innovative use of standardized fractions in HT content as precursors for the synthesis of new biologically active molecules with rich bioavailability have already been processed. For this reason, the olive tree is an unmatched sustained resource for unique bioactive compounds with diverse health benefits.

Author Contributions: Conceptualization A.R., A.N., and R.B.; Writing-Original Draft Preparation F.I., S.U., G.M., and C.N.; Writing-Review and Editing A.R., A.N., and R.B. All authors read and approved the final manuscript.

Funding: This research received no external funding.

Acknowledgments: The authors thank EXTRANUTRAOILS Project (DM n.30311, October 31st 2018, Ministero delle Politiche Agricole e Forestali-MIPAF) and Federazione Medico Sportiva Italiana for financial support; Caterina Gola for the revision of the English language.

Conflicts of Interest: The authors declare no conflicts of interest.

\section{Abbreviation List}

$\begin{array}{ll}\text { CKD } & \text { Chronic kidney disease } \\ \text { COX-1 } & \text { Ciclooxygenase-1 } \\ \text { COX-2 } & \text { Ciclooxygenase-2 } \\ \text { CV } & \text { Cardiovascular } \\ \text { CVD } & \text { Cardiovascular disease } \\ \text { DXR } & \text { Doxorubicin } \\ \text { EFSA } & \text { European Food Safety Authority } \\ \text { EPIC } & \text { European Prospective Investigation into Cancer and Nutrition } \\ \text { EPICOR } & \text { Long-term follow-up of antithrombotic management patterns on acute coronary syndrome } \\ \text { EU } & \text { patients } \\ \text { EVOO } & \text { European Union } \\ \text { Hcy } & \text { Extra-virgin olive oil } \\ \text { HDL } & \text { Homocysteine } \\ \text { HPLC-DAD } & \text { High density lipoproteins } \\ \text { HPLC-MS } & \text { High performance liquid chromatography-diode array detector } \\ \text { HT } & \text { High performance liquid chromatography-mass detector } \\ \text { HUVEC } & \text { Hydroxytyrosol } \\ \text { IMD } & \text { Human endothelial cells } \\ \text { IMOD } & \text { Italian Mediterranean diet } \\ \text { IOC } & \text { Italian Mediterranean organic diet } \\ \text { K-DOQI } & \text { International Olive Council } \\ \text { LDL } & \text { Kidney-Disease Outcomes Quality Initiative } \\ \text { LOX-1 } & \text { Low density lipoprotein } \\ \text { MD } & \text { Lectin-like oxidized LDL receptor-1 } \\ & \text { Mediterranean diet }\end{array}$




$\begin{array}{ll}\text { MDM } & \text { Monocyte- derived macrophages } \\ \text { MFA } & \text { Membrane Filtration Absorption } \\ \text { MTHFR } & \text { Methylenetetrahydrofolate reductase } \\ \text { NCD } & \text { Chronic non-communicable disease } \\ \text { NF-kB } & \text { Nuclear factor kappa-light-chain-enhancer of activated B cells } \\ \text { NO } & \text { Nitric oxide } \\ \text { OLC } & \text { Oleocanthal } \\ \text { OLE } & \text { Oleuropein } \\ \text { OO } & \text { Olive oil } \\ \text { OxLDL } & \text { Oxidized low density lipoprotein } \\ \text { PMA } & \text { Phorbol-myristate acetate } \\ \text { PPAR- } \gamma & \text { Peroxisome proliferator-activated receptor gamma } \\ \text { RCT } & \text { Randomized controlled trial } \\ \text { ROS } & \text { Reactive oxygen species } \\ \text { SASP } & \text { Senescence-associated-secretory-phenotype } \\ \text { SCSCD } & \text { Seven Country Study of Cardiovascular Disease } \\ \text { SOP } & \text { Stoned Olive Pomace } \\ \text { TRPA1 } & \text { Transient receptor potential channel, subfamily A, member 1 } \\ \text { Tyr } & \text { Tyrosol } \\ \text { UNESCO } & \text { United Nations Educational Scientific and Cultural Organization }\end{array}$

\section{References}

1. Bosku, D. Olive Oil. In Mediterranean Diets; Simopoulos, A.P., Visioli, F., Eds.; Karger Publishers: Basel, Switzerland, 2000; pp. 56-77.

2. Nocella, C.; Cammisotto, V.; Fianchini, L.; D'Amico, A.; Novo, M.; Castellani, V.; Stefanini, L.; Violi, F.; Carnevale, R. Extra Virgin Olive Oil and Cardiovascular Diseases: Benefits for Human Health. Endocr. Metab. Immune Disord. Drug Targets 2018, 18, 4-13. [CrossRef] [PubMed]

3. Codex Alimentarius-International Food Standards. Available online: http://www.fao.org/fao-whocodexalimentarius/en/ (accessed on 4 April 2019).

4. Sroka, Z.; Cisowski, W. Hydrogen peroxide scavenging, antioxidant and anti-radical activity of some phenolic acids. Food Chem. Toxicol. 2003, 41,753-758. [CrossRef]

5. López-Biedma, A.; Sánchez-Quesada, C.; Delgado-Rodríguez, M.; Gaforio, J.J. The biological activities of natural lignans from olives and virgin olive oils: A review. J. Funct. Foods 2016, 26, 36-47. [CrossRef]

6. Gambacorta, A.; Tofani, D.; Bernini, R.; Migliorini, A. High-yielding preparation of a stable precursor of hydroxytyrosol by total synthesis and from the natural glycoside oleuropein. J. Agric. Food Chem. 2007, 55, 3386-3391. [CrossRef] [PubMed]

7. Romani, A.; Pinelli, P.; Ieri, F.; Bernini, R. Sustainability, Innovation, and Green Chemistry in the Production and Valorization of Phenolic Extracts from Olea europaea L. Sustainability 2016, 8, 1002. [CrossRef]

8. Mulinacci, N.; Romani, A.; Galardi, C.; Pinelli, P.; Giaccherini, C.; Vincieri, F.F. Polyphenolic content in olive oil waste waters and related olive samples. J. Agric. Food Chem. 2001, 49, 3509-3514. [CrossRef] [PubMed]

9. Adriaanse, A.; Bringezu, S.; Hamond, A.; Moriguchi, Y.; Rodenburg, E.; Rogich, D.; Schütz, H. Resource Flows: The Material Base of Industrial Economies; World Resources Institute: Washington, DC, USA, 1997; Available online: http://pdf.wri.org/resourceflows_w.pdf (accessed on 15 March 2019).

10. Brunner, P.H.; Rechberger, H. Practical Handbook of Material Flow Analysis; CRC Press LLC.: Boca Raton, FL, USA, 2004.

11. Garcia-Castello, E.; Cassano, A.; Criscuoli, A.; Conidi, C.; Drioli, E. Recovery and concentration of polyphenols from olive mill wastewaters by integrated membrane system. Water Res. 2010, 44, 3883-3892. [CrossRef]

12. Cassano, A.; Conidi, C.; Giorno, L.; Drioli, E. Fractionation of olive mill wastewaters by membrane separation techniques. J. Hazard. Mater. 2013, 248, 185-193. [CrossRef]

13. Romani, A.; Scardigli, A.; Pinelli, P. An environmentally friendly process for the production of extracts rich in phenolic antioxidants from Olea europaea L. and Cynara scolymus L. matrices. Eur. Food Res. Technol. 2017, 243, 1229-1238. [CrossRef] 
14. Pizzichini, D.; Russo, C.; Vitagliano, M.; Pizzichini, M.; Romani, A.; Ieri, F.; Pinelli, P.; Vignolini, P. Process for producing concentrated and refined actives from tissues and byproducts of Olea europaea with membrane technologies. Patent No. EP2338500A1, 29 June 2011.

15. Roig, A.; Cayuela, M.L.; Sanchez-Monedero, M.A. An overview on olive mill wastes and their valorisation methods. Waste Manag. 2006, 26, 960-969. [CrossRef]

16. Keys, A.; Menotti, A.; Karvonen, M.J.; Aravanis, C.; Blackburn, H.; Buzina, R.; Djordjevic, B.S.; Dontas, A.S.; Fidanza, F.; Keys, M.H.; et al. The diet and 15-year death rate in the seven countries study. Am. J. Epidemiol. 1986, 124, 903-915. [CrossRef]

17. Di Daniele, N.; Noce, A.; Vidiri, M.F.; Moriconi, E.; Marrone, G.; Annicchiarico-Petruzzelli, M.; D’Urso, G.; Tesauro, M.; Rovella, V.; De Lorenzo, A. Impact of Mediterranean diet on metabolic syndrome, cancer and longevity. Oncotarget 2017, 8, 8947-8979. [CrossRef]

18. Xavier Medina, F. Mediterranean diet, culture and heritage: Challenges for a new conception. Public Health Nutr. 2009, 12, 1618-1620. [CrossRef]

19. Grosso, G.; Pajak, A.; Mistretta, A.; Marventano, S.; Raciti, T.; Buscemi, S.; Drago, F.; Scalfi, L.; Galvano, F. Protective role of the Mediterranean diet on several cardiovascular risk factors: Evidence from Sicily, southern Italy. Nutr. Metab. Cardiovasc. Dis. 2014, 24, 370-377. [CrossRef]

20. Grosso, G.; Marventano, S.; Yang, J.; Micek, A.; Pajak, A.; Scalfi, L.; Galvano, F.; Kales, S.N. A comprehensive meta-analysis on evidence of Mediterranean diet and cardiovascular disease: Are individual components equal? Crit. Rev. Food Sci. Nutr. 2017, 57, 3218-3232. [CrossRef]

21. Di Daniele, N.; Petramala, L.; Di Renzo, L.; Sarlo, F.; Della Rocca, D.G.; Rizzo, M.; Fondacaro, V.; Iacopino, L.; Pepine, C.J.; De Lorenzo, A. Body composition changes and cardiometabolic benefits of a balanced Italian Mediterranean Diet in obese patients with metabolic syndrome. Acta Diabetol. 2013, 50, 409-416. [CrossRef]

22. De Lorenzo, A.; Noce, A.; Bigioni, M.; Calabrese, V.; Della Rocca, D.G.; Di Daniele, N.; Tozzo, C.; Di Renzo, L. The effects of Italian Mediterranean organic diet (IMOD) on health status. Curr. Pharm. Des. 2010, 16, 814-824. [CrossRef]

23. Di Daniele, N.; Di Renzo, L.; Noce, A.; Iacopino, L.; Ferraro, P.M.; Rizzo, M.; Sarlo, F.; Domino, E.; De Lorenzo, A. Effects of Italian Mediterranean organic diet vs. low-protein diet in nephropathic patients according to MTHFR genotypes. J. Nephrol. 2014, 27, 529-536. [CrossRef]

24. Estruch, R.; Ros, E.; Salas-Salvado, J.; Covas, M.I.; Corella, D.; Aros, F.; Gomez-Gracia, E.; Ruiz-Gutierrez, V.; Fiol, M.; Lapetra, J.; et al. Primary Prevention of Cardiovascular Disease with a Mediterranean Diet Supplemented with Extra-Virgin Olive Oil or Nuts. N. Engl. J. Med. 2018, 378, e34. [CrossRef]

25. De Lorgeril, M.; Renaud, S.; Mamelle, N.; Salen, P.; Martin, J.L.; Monjaud, I.; Guidollet, J.; Touboul, P.; Delaye, J. Mediterranean alpha-linolenic acid-rich diet in secondary prevention of coronary heart disease. Lancet 1994, 343, 1454-1459. [CrossRef]

26. McLennan, P.L. Relative effects of dietary saturated, monounsaturated, and polyunsaturated fatty acids on cardiac arrhythmias in rats. Am. J. Clin. Nutr. 1993, 57, 207-212. [CrossRef]

27. Kopple, J.D. National kidney foundation K/DOQI clinical practice guidelines for nutrition in chronic renal failure. Am. J. Kidney Dis. 2001, 37, S66-S70. [CrossRef]

28. Zhang, X.; Li, H.; Jin, H.; Ebin, Z.; Brodsky, S.; Goligorsky, M.S. Effects of homocysteine on endothelial nitric oxide production. Am. J. Physiol. Renal. Physiol. 2000, 279, F671-F678. [CrossRef]

29. Pastore, A.; Noce, A.; Di Giovamberardino, G.; De Stefano, A.; Calla, C.; Zenobi, R.; Dessi, M.; Di Daniele, N. Homocysteine, cysteine, folate and vitamin $\mathrm{B}(1)(2)$ status in type 2 diabetic patients with chronic kidney disease. J. Nephrol. 2015, 28, 571-576. [CrossRef]

30. EFSA. Panel on Dietetic Products. EFSA J. 2011, 9, 2033-2058.

31. EFSA. Scientific Opinion on the substantiation of health claims related to polyphenols in olive and protection of LDL particles from oxidative damage (ID 1333, 1638, 1639, 1696, 2865), maintenance of normal blood HDL cholesterol concentrations (ID 1639), maintenance of normal blood pressure (ID 3781), "anti-inflammatory properties" (ID 1882), "contributes to the upper respiratory tract health" (ID 3468), "can help to maintain a normal function of gastrointestinal tract" (3779), and "contributes to body defences against external agents" (ID 3467) pursuant to Article 13(1) of Regulation (EC) No 1924/2006. Available online: https://www.efsa.europa.eu/en/efsajournal/pub/2033 (accessed on 5 April 2019). 
32. Dunn, S.; Vohra, R.S.; Murphy, J.E.; Homer-Vanniasinkam, S.; Walker, J.H.; Ponnambalam, S. The lectin-like oxidized low-density-lipoprotein receptor: A pro-inflammatory factor in vascular disease. Biochem. J. 2008, 409, 349-355. [CrossRef]

33. Zambonin, L.; Caliceti, C.; Vieceli Dalla Sega, F.; Fiorentini, D.; Hrelia, S.; Landi, L.; Prata, C. Dietary phenolic acids act as effective antioxidants in membrane models and in cultured cells, exhibiting proapoptotic effects in leukaemia cells. Oxidative Med. Cell. Longev. 2012, 2012. [CrossRef]

34. Dell'Agli, M.; Fagnani, R.; Mitro, N.; Scurati, S.; Masciadri, M.; Mussoni, L.; Galli, G.V.; Bosisio, E.; Crestani, M.; De Fabiani, E.; et al. Minor components of olive oil modulate proatherogenic adhesion molecules involved in endothelial activation. J. Agric. Food Chem. 2006, 54, 3259-3264. [CrossRef]

35. Visioli, F.; Galli, C.; Bornet, F.; Mattei, A.; Patelli, R.; Galli, G.; Caruso, D. Olive oil phenolics are dose-dependently absorbed in humans. FEBS Lett. 2000, 468, 159-160. [CrossRef]

36. Covas, M.I. Olive oil and the cardiovascular system. Pharmacol. Res. 2007, 55, 175-186. [CrossRef]

37. Cicerale, S.; Lucas, L.J.; Keast, R.S. Antimicrobial, antioxidant and anti-inflammatory phenolic activities in extra virgin olive oil. Curr. Opin. Biotechnol. 2012, 23, 129-135. [CrossRef]

38. Incani, A.; Serra, G.; Atzeri, A.; Melis, M.P.; Serreli, G.; Bandino, G.; Sedda, P.; Campus, M.; Tuberoso, C.I.; Deiana, M. Extra virgin olive oil phenolic extracts counteract the pro-oxidant effect of dietary oxidized lipids in human intestinal cells. Food Chem. Toxicol. 2016, 90, 171-180. [CrossRef]

39. Serreli, G.; Deiana, M. Biological Relevance of Extra Virgin Olive Oil Polyphenols Metabolites. Antioxidants 2018, 7, 170. [CrossRef]

40. Franconi, F.; Coinu, R.; Carta, S.; Urgeghe, P.P.; Ieri, F.; Mulinacci, N.; Romani, A. Antioxidant effect of two virgin olive oils depends on the concentration and composition of minor polar compounds. J. Agric. Food Chem. 2006, 54, 3121-3125. [CrossRef]

41. Manna, C.; D’Angelo, S.; Migliardi, V.; Loffredi, E.; Mazzoni, O.; Morrica, P.; Galletti, P.; Zappia, V. Protective effect of the phenolic fraction from virgin olive oils against oxidative stress in human cells. J. Agric. Food Chem. 2002, 50, 6521-6526. [CrossRef]

42. Salvini, S.; Sera, F.; Caruso, D.; Giovannelli, L.; Visioli, F.; Saieva, C.; Masala, G.; Ceroti, M.; Giovacchini, V.; Pitozzi, V.; et al. Daily consumption of a high-phenol extra-virgin olive oil reduces oxidative DNA damage in postmenopausal women. Br. J. Nutr. 2006, 95, 742-751. [CrossRef]

43. Covas, M.I.; Nyyssonen, K.; Poulsen, H.E.; Kaikkonen, J.; Zunft, H.J.; Kiesewetter, H.; Gaddi, A.; de la Torre, R.; Mursu, J.; Baumler, H.; et al. The effect of polyphenols in olive oil on heart disease risk factors: A randomized trial. Ann. Int. Med. 2006, 145, 333-341. [CrossRef]

44. Perez-Herrera, A.; Delgado-Lista, J.; Torres-Sanchez, L.A.; Rangel-Zuniga, O.A.; Camargo, A.; Moreno-Navarrete, J.M.; Garcia-Olid, B.; Quintana-Navarro, G.M.; Alcala-Diaz, J.F.; Munoz-Lopez, C.; et al. The postprandial inflammatory response after ingestion of heated oils in obese persons is reduced by the presence of phenol compounds. Mol. Nutr. Food Res. 2012, 56, 510-514. [CrossRef]

45. Souza, P.A.L.; Marcadenti, A.; Portal, V.L. Effects of Olive Oil Phenolic Compounds on Inflammation in the Prevention and Treatment of Coronary Artery Disease. Nutrients 2017, 9, 1087. [CrossRef]

46. Tousoulis, D.; Charakida, M.; Stefanadis, C. Endothelial function and inflammation in coronary artery disease. Heart 2006, 92, 441-444. [CrossRef]

47. Widmer, R.J.; Lerman, A. Endothelial dysfunction and cardiovascular disease. Glob. Cardiol. Sci. Pract. 2014, 2014, 291-308. [CrossRef]

48. Brunelleschi, S.; Bardelli, C.; Amoruso, A.; Gunella, G.; Ieri, F.; Romani, A.; Malorni, W.; Franconi, F. Minor polar compounds extra-virgin olive oil extract (MPC-OOE) inhibits NF-kappa B translocation in human monocyte/macrophages. Pharmacol. Res. 2007, 56, 542-549. [CrossRef]

49. Visioli, F.; Galli, C. Olive Oil Phenols and Their Potential Effects on Human Health. J. Agric. Food Chem. 1998, 10, 4292-4296. [CrossRef]

50. De Lorenzo, A.; Noce, A.; Moriconi, E.; Rampello, T.; Marrone, G.; Di Daniele, N.; Rovella, V. MOSH Syndrome (Male Obesity Secondary Hypogonadism): Clinical Assessment and Possible Therapeutic Approaches. Nutrients 2018, 10, 474. [CrossRef]

51. Francisco, V.; Ruiz-Fernandez, C.; Lahera, V.; Lago, F.; Pino, J.; Skaltsounis, L.; Gonzalez-Gay, M.A.; Mobasheri, A.; Gomez, R.; Scotece, M.; et al. Natural Molecules for Healthy Lifestyles: Oleocanthal from Extra Virgin Olive Oil. J. Agric. Food Chem. 2019, 67, 3845-3853. [CrossRef] 
52. Cicerale, S.; Breslin, P.A.; Beauchamp, G.K.; Keast, R.S. Sensory characterization of the irritant properties of oleocanthal, a natural anti-inflammatory agent in extra virgin olive oils. Chem. Senses 2009, 34, 333-339. [CrossRef]

53. Peyrot des Gachons, C.; Uchida, K.; Bryant, B.; Shima, A.; Sperry, J.B.; Dankulich-Nagrudny, L.; Tominaga, M.; Smith, A.B., 3rd; Beauchamp, G.K.; Breslin, P.A. Unusual pungency from extra-virgin olive oil is attributable to restricted spatial expression of the receptor of oleocanthal. J. Neurosci. 2011, 31, 999-1009. [CrossRef]

54. Beauchamp, G.K.; Keast, R.S.; Morel, D.; Lin, J.; Pika, J.; Han, Q.; Lee, C.H.; Smith, A.B.; Breslin, P.A. Phytochemistry: Ibuprofen-like activity in extra-virgin olive oil. Nature 2005, 437, 45-46. [CrossRef]

55. Parkinson, L.; Keast, R. Oleocanthal, a phenolic derived from virgin olive oil: A review of the beneficial effects on inflammatory disease. Int. J. Mol. Sci. 2014, 15, 12323-12334. [CrossRef]

56. Harris, R.E.; Beebe-Donk, J.; Doss, H.; Burr Doss, D. Aspirin, ibuprofen, and other non-steroidal anti-inflammatory drugs in cancer prevention: A critical review of non-selective COX-2 blockade (review). Oncol. Rep. 2005, 13, 559-583. [CrossRef]

57. Zhou, Y.; Su, Y.; Li, B.; Liu, F.; Ryder, J.W.; Wu, X.; Gonzalez-DeWhitt, P.A.; Gelfanova, V.; Hale, J.E.; May, P.C.; et al. Nonsteroidal anti-inflammatory drugs can lower amyloidogenic Abeta42 by inhibiting Rho. Science 2003, 302, 1215-1217. [CrossRef]

58. May, A.E.; Seizer, P.; Gawaz, M. Platelets: Inflammatory firebugs of vascular walls. Arterioscler. Thromb. Vasc. Biol. 2008, 28, s5-s10. [CrossRef]

59. Segura-Carretero, A.; Curiel, J.A. Current Disease-Targets for Oleocanthal as Promising Natural Therapeutic Agent. Int. J. Mol. Sci. 2018, 19, 2899. [CrossRef]

60. Agrawal, K.; Melliou, E.; Li, X.; Pedersen, T.L.; Wang, S.C.; Magiatis, P.; Newman, J.W.; Holt, R.R. Oleocanthal-rich extra virgin olive oil demonstrates acute anti-platelet effects in healthy men in a randomized trial. J. Funct. Foods 2017, 36, 84-93. [CrossRef]

61. Priora, R.; Summa, D.; Frosali, S.; Margaritis, A.; Di Giuseppe, D.; Lapucci, C.; Ieri, F.; Pulcinelli, F.M.; Romani, A.; Franconi, F.; et al. Administration of minor polar compound-enriched extra virgin olive oil decreases platelet aggregation and the plasma concentration of reduced homocysteine in rats. J. Nutr. 2008, 138, 36-41. [CrossRef]

62. Carrasco-Pancorbo, A.; Cerretani, L.; Bendini, A.; Segura-Carretero, A.; Del Carlo, M.; Gallina-Toschi, T.; Lercker, G.; Compagnone, D.; Fernandez-Gutierrez, A. Evaluation of the antioxidant capacity of individual phenolic compounds in virgin olive oil. J. Agric. Food Chem. 2005, 53, 8918-8925. [CrossRef]

63. Vuorela, S.; Kreander, K.; Karonen, M.; Nieminen, R.; Hamalainen, M.; Galkin, A.; Laitinen, L.; Salminen, J.P.; Moilanen, E.; Pihlaja, K.; et al. Preclinical evaluation of rapeseed, raspberry, and pine bark phenolics for health related effects. J. Agric. Food Chem. 2005, 53, 5922-5931. [CrossRef]

64. Menendez, J.A.; Vazquez-Martin, A.; Oliveras-Ferraros, C.; Garcia-Villalba, R.; Carrasco-Pancorbo, A.; Fernandez-Gutierrez, A.; Segura-Carretero, A. Analyzing effects of extra-virgin olive oil polyphenols on breast cancer-associated fatty acid synthase protein expression using reverse-phase protein microarrays. Int. J. Mol. Med. 2008, 22, 433-439. [CrossRef]

65. Fini, L.; Hotchkiss, E.; Fogliano, V.; Graziani, G.; Romano, M.; De Vol, E.B.; Qin, H.; Selgrad, M.; Boland, C.R.; Ricciardiello, L. Chemopreventive properties of pinoresinol-rich olive oil involve a selective activation of the ATM-p53 cascade in colon cancer cell lines. Carcinogenesis 2008, 29, 139-146. [CrossRef]

66. Wongwarawipat, T.; Papageorgiou, N.; Bertsias, D.; Siasos, G.; Tousoulis, D. Olive Oil-related Anti-inflammatory Effects on Atherosclerosis: Potential Clinical Implications. Endocr. Metab. Immune Disord. Drug Targets 2018, 18, 51-62. [CrossRef]

67. Santangelo, C.; Vari, R.; Scazzocchio, B.; De Sanctis, P.; Giovannini, C.; D’Archivio, M.; Masella, R. Anti-inflammatory Activity of Extra Virgin Olive Oil Polyphenols: Which Role in the Prevention and Treatment of Immune-Mediated Inflammatory Diseases? Endocr. Metab. Immune Disord. Drug Targets 2018, 18, 36-50. [CrossRef]

68. Riboli, E.; Hunt, K.J.; Slimani, N.; Ferrari, P.; Norat, T.; Fahey, M.; Charrondiere, U.R.; Hemon, B.; Casagrande, C.; Vignat, J.; et al. European Prospective Investigation into Cancer and Nutrition (EPIC): Study populations and data collection. Public Health Nutr. 2002, 5, 1113-1124. [CrossRef]

69. Park, J.Y.; Nicolas, G.; Freisling, H.; Biessy, C.; Scalbert, A.; Romieu, I.; Chajes, V.; Chuang, S.C.; Ericson, U.; Wallstrom, P.; et al. Comparison of standardised dietary folate intake across ten countries participating in the European Prospective Investigation into Cancer and Nutrition. Br. J. Nutr. 2012, 108, 552-569. [CrossRef] 
70. Sieri, S.; Agnoli, C.; Pala, V.; Mattiello, A.; Panico, S.; Masala, G.; Assedi, M.; Tumino, R.; Frasca, G.; Sacerdote, C.; et al. Dietary habits and cancer: The experience of epic-Italy. Epidemiologia e Prevenzione 2015, 39, 333-338.

71. Noce, A.; Marrone, G.; Di Daniele, F.; Ottaviani, E.; Wilson Jones, G.; Bernini, R.; Romani, A.; Rovella, V. Impact of Gut Microbiota Composition on Onset and Progression of Chronic Non-Communicable Diseases. Nutrients 2019, 11, 1073. [CrossRef]

72. Masala, G.; Ceroti, M.; Pala, V.; Krogh, V.; Vineis, P.; Sacerdote, C.; Saieva, C.; Salvini, S.; Sieri, S.; Berrino, F.; et al. A dietary pattern rich in olive oil and raw vegetables is associated with lower mortality in Italian elderly subjects. Br. J. Nutr. 2007, 98, 406-415. [CrossRef]

73. Bendinelli, B.; Masala, G.; Saieva, C.; Salvini, S.; Calonico, C.; Sacerdote, C.; Agnoli, C.; Grioni, S.; Frasca, G.; Mattiello, A.; et al. Fruit, vegetables, and olive oil and risk of coronary heart disease in Italian women: The EPICOR Study. Am. J. Clin. Nutr. 2011, 93, 275-283. [CrossRef]

74. Mills, S.; Stanton, C.; Lane, J.A.; Smith, G.J.; Ross, R.P. Precision Nutrition and the Microbiome, Part I: Current State of the Science. Nutrients 2019, 11, 923. [CrossRef]

75. Sender, R.; Fuchs, S.; Milo, R. Are We Really Vastly Outnumbered? Revisiting the Ratio of Bacterial to Host Cells in Humans. Cell 2016, 164, 337-340. [CrossRef]

76. Cani, P.D. Human gut microbiome: Hopes, threats and promises. Gut 2018, 67, 1716-1725. [CrossRef]

77. Gavahian, M.; Khaneghah, A.M.; Lorenzo, J.M.; Munekata, P.E.; Garcia-Mantrana, I.; Carmen Collado, M.; Melendez-Martinez, A.J.; Barba, F.J. Health benefits of olive oil and its components: Impacts on gut microbiota antioxidant activities, and prevention of noncommunicable diseases. Trends Food Sci. Technol. 2019. [CrossRef]

78. Pallara, G.; Buccioni, A.; Pastorelli, R.; Minieri, S.; Mele, M.; Rapaccini, S.; Messini, A.; Pauselli, M.; Servili, M.; Giovannetti, L.; et al. Effect of stoned olive pomace on rumen microbial communities and polyunsaturated fatty acid biohydrogenation: An in vitro study. BMC Vet. Res. 2014, 10. [CrossRef]

79. Martinez, N.; Prieto, I.; Hidalgo, M.; Segarra, A.B.; Martinez-Rodriguez, A.M.; Cobo, A.; Ramirez, M.; Galvez, A.; Martinez-Canamero, M. Refined versus Extra Virgin Olive Oil High-Fat Diet Impact on Intestinal Microbiota of Mice and Its Relation to Different Physiological Variables. Microorganisms 2019, 7, 61. [CrossRef]

80. Prieto, I.; Hidalgo, M.; Segarra, A.B.; Martinez-Rodriguez, A.M.; Cobo, A.; Ramirez, M.; Abriouel, H.; Galvez, A.; Martinez-Canamero, M. Influence of a diet enriched with virgin olive oil or butter on mouse gut microbiota and its correlation to physiological and biochemical parameters related to metabolic syndrome. PLoS ONE 2018, 13, e0190368. [CrossRef]

81. Hidalgo, M.; Prieto, I.; Abriouel, H.; Villarejo, A.B.; Ramirez-Sanchez, M.; Cobo, A.; Benomar, N.; Galvez, A.; Martinez-Canamero, M. Changes in Gut Microbiota Linked to a Reduction in Systolic Blood Pressure in Spontaneously Hypertensive Rats Fed an Extra Virgin Olive Oil-Enriched Diet. Plant Foods Hum. Nutr. 2018, 73. [CrossRef]

82. Martin-Pelaez, S.; Castaner, O.; Sola, R.; Motilva, M.J.; Castell, M.; Perez-Cano, F.J.; Fito, M. Influence of Phenol-Enriched Olive Oils on Human Intestinal Immune Function. Nutrients 2016, 8, 213. [CrossRef]

83. Fiorentino, A.; Gentili, A.; Isidori, M.; Monaco, P.; Nardelli, A.; Parrella, A.; Temussi, F. Environmental effects caused by olive mill wastewaters: Toxicity comparison of low-molecular-weight phenol components. J. Agric. Food Chem. 2003, 51, 1005-1009. [CrossRef]

84. Cecchi, L.; Bellumori, M.; Cipriani, C.; Mocali, A.; Innocenti, M.; Mulinacci, N.; Giovannelli, L. A two-phase olive mill by-product (pâté) as a convenient source of phenolic compounds: Content, stability, and antiaging properties in cultured human fibroblasts. J. Funct. Foods 2018, 40, 751-759. [CrossRef]

85. Bellumori, M.; Cecchi, L.; Romani, A.; Mulinacci, N.; Innocenti, M. Recovery and stability over time of phenolic fractions by an industrial filtration system of olive mill wastewaters: A three-year study. J. Sci. Food Agric. 2018, 98, 2761-2769. [CrossRef]

86. Cecchi, L.; Migliorini, M.; Zanoni, B.; Breschi, C.; Mulinacci, N. An effective HPLC-based approach for the evaluation of the content of total phenolic compounds transferred from olives to virgin olive oil during the olive milling process. J. Sci. Food Agric. 2018, 98, 3636-3643. [CrossRef]

87. Schaffer, S.; Muller, W.E.; Eckert, G.P. Cytoprotective effects of olive mill wastewater extract and its main constituent hydroxytyrosol in PC12 cells. Pharmacol. Res. 2010, 62, 322-327. [CrossRef] 
88. Obied, H.K.; Bedgood, D.R., Jr.; Prenzler, P.D.; Robards, K. Bioscreening of Australian olive mill waste extracts: Biophenol content, antioxidant, antimicrobial and molluscicidal activities. Food Chem. Toxicol. 2007, 45, 1238-1248. [CrossRef]

89. Bernini, R.M.E.; Barontini, M.; Crisante, F. Convenient synthesis of hydroxytyrosol and its lipophilic derivatives from tyrosol or homovanillyl alcohol. J. Agric. Food Chem. 2008, 56, 8897-8904. [CrossRef]

90. Bernini, R.C.S.; Fabrizi, G.; Filisti, E. 2-Arylhydroxytyrosol derivatives via Suzuki-Miyaura cross-coupling. Org. Lett. 2008, 10, 3457-3460. [CrossRef]

91. Bernini, R.; Crisante, F.; Merendino, N.; Molinari, R.; Soldatelli, M.C.; Velotti, F. Synthesis of a novel ester of hydroxytyrosol and alpha-lipoic acid exhibiting an antiproliferative effect on human colon cancer HT-29 cells. Eur. J. Med. Chem. 2011, 46, 439-446. [CrossRef]

92. Barontini, M.B.R.; Carastro, R.; Gentili, P.; Romani, A. Synthesis and DPPH radical scavenging activity of novel compounds obtained from tyrosol and cinnamic acid derivatives. New J. Chem. 2014, 38, 809-816. [CrossRef]

93. Bernini, R.; Carastro, I.; Palmini, G.; Tanini, A.; Zonefrati, R.; Pinelli, P.; Brandi, M.L.; Romani, A. Lipophilization of Hydroxytyrosol-Enriched Fractions from Olea europaea L. Byproducts and Evaluation of the in Vitro Effects on a Model of Colorectal Cancer Cells. J. Agric. Food Chem. 2017, 65, 6506-6512. [CrossRef]

94. Bernini, R.; Carastro, I.; Santoni, F.; Clemente, M. Synthesis of lipophilic esters of tyrosol, homovanillyl alcohol and hydroxytyrosol. Antioxidants 2019, 8, 174. [CrossRef]

95. Plastina, P.B.C.; Perri, E.; Fazio, A.; Augimeri, G.; Poland, M.; Witkamp, R.; Meijerink, J. Identification of hydroxytyrosyl oleate, a derivative of hydroxytyrosol with anti-inflammatory properties, in olive oil by-product. Food Chem. 2019, 279, 105-113. [CrossRef]

96. Visioli, F.W.R.; Richard, D.; Abdullah, M.I.C.B.; Crea, R. Olive phenolics increase glutathione levels in healthy volunteers. J. Agric. Food Chem. 2009, 57, 1793-1796. [CrossRef]

97. DellaGreca, M.; Previtera, L.; Temussi, F.; Zarrelli, A. Low-molecular-weight components of olive oil mill waste-waters. Phytochem. Anal. 2004, 15, 184-188. [CrossRef]

98. Massei, G.; Hartley, S.E. Disarmed by domestication? Induced responses to browsing in wild and cultivated olive. Oecologia 2000, 122, 225-231. [CrossRef]

99. Özcan, M.M.; Matthäus, B. A review: Benefit and bioactive properties of olive (Olea europaea L.) leaves. Eur. Food Res. Technol. 2017. [CrossRef]

100. Andrikopoulos, N.K.; Kaliora, A.C.; Assimopoulou, A.N.; Papageorgiou, V.P. Inhibitory activity of minor polyphenolic and nonpolyphenolic constituents of olive oil against in vitro low-density lipoprotein oxidation. J. Med. Food 2002, 5. [CrossRef]

101. Janahmadi, Z.; Nekooeian, A.A.; Moaref, A.R.; Emamghoreishi, M. Oleuropein attenuates the progression of heart failure in rats by antioxidant and antiinflammatory effects. Naunyn Schmiedebergs Arch. Pharmacol. 2017, 390, 245-252. [CrossRef]

102. Jemai, H.; El Feki, A.; Sayadi, S. Antidiabetic and antioxidant effects of hydroxytyrosol and oleuropein from olive leaves in alloxan-diabetic rats. J. Agric. Food Chem. 2009, 57, 8798-8804. [CrossRef]

103. Carnevale, R.; Silvestri, R.; Loffredo, L.; Novo, M.; Cammisotto, V.; Castellani, V.; Bartimoccia, S.; Nocella, C.; Violi, F. Oleuropein, a component of extra virgin olive oil, lowers postprandial glycaemia in healthy subjects. Br. J. Clin. Pharmacol. 2018, 84, 1566-1574. [CrossRef]

104. De Bock, M.; Derraik, J.G.; Brennan, C.M.; Biggs, J.B.; Morgan, P.E.; Hodgkinson, S.C.; Hofman, P.L.; Cutfield, W.S. Olive (Olea europaea L.) leaf polyphenols improve insulin sensitivity in middle-aged overweight men: A randomized, placebo-controlled, crossover trial. PLoS ONE 2013, 8, e57622. [CrossRef]

105. Papachristodoulou, A.; Tsoukala, M.; Benaki, D.; Kostidis, S.; Gioti, K.; Aligiannis, N.; Pratsinis, H.; Kletsas, D.; Skaltsounis, A.; Mikros, E.; et al. Oleuropein is a Powerful Sensitizer of Doxorubicin-mediated Killing of Prostate Cancer Cells and Exerts Its Action via Induction of Autophagy. J. Cancer Res. Treat 2016, 4, 61-68. [CrossRef]

106. Elamin, M.H.; Elmahi, A.B.; Daghestani, M.H.; Al-Olayan, E.M.; Al-Ajmi, R.A.; Alkhuriji, A.F.; Hamed, S.S.; Elkhadragy, M.F. Synergistic Anti-Breast-Cancer Effects of Combined Treatment with Oleuropein and Doxorubicin In Vivo. Altern. Ther. 2019, 25, 17-24. 
107. Sudjana, A.N.; D’Orazio, C.; Ryan, V.; Rasool, N.; Ng, J.; Islam, N.; Riley, T.V.; Hammer, K.A. Antimicrobial activity of commercial Olea europaea (olive) leaf extract. Int. J. Antimicrob. Agents 2009, 33, 461-463. [CrossRef]

108. Miceli, C.; Santin, Y.; Manzella, N.; Coppini, R.; Berti, A.; Stefani, M.; Parini, A.; Mialet-Perez, J.; Nediani, C. Oleuropein Aglycone Protects against MAO-A-Induced Autophagy Impairment and Cardiomyocyte Death through Activation of TFEB. Oxid. Med. Cell. Longev. 2018, 2018. [CrossRef]

109. Rigacci, S.; Guidotti, V.; Bucciantini, M.; Parri, M.; Nediani, C.; Cerbai, E.; Stefani, M.; Berti, A. Oleuropein aglycon prevents cytotoxic amyloid aggregation of human amylin. J. Nutr. Biochem. 2010, 21, 726-735. [CrossRef]

110. Rigacci, S.; Guidotti, V.; Bucciantini, M.; Nichino, D.; Relini, A.; Berti, A.; Stefani, M. Abeta(1-42) aggregates into non-toxic amyloid assemblies in the presence of the natural polyphenol oleuropein aglycon. Curr. Alzheimer Res. 2011, 8, 841-852. [CrossRef]

111. Rigacci, S.; Miceli, C.; Nediani, C.; Berti, A.; Cascella, R.; Pantano, D.; Nardiello, P.; Luccarini, I.; Casamenti, F.; Stefani, M. Oleuropein aglycone induces autophagy via the AMPK/mTOR signalling pathway: A mechanistic insight. Oncotarget 2015, 6, 35344-35357. [CrossRef]

112. Luccarini, I.; Pantano, D.; Nardiello, P.; Cavone, L.; Lapucci, A.; Miceli, C.; Nediani, C.; Berti, A.; Stefani, M.; Casamenti, F. The Polyphenol Oleuropein Aglycone Modulates the PARP1-SIRT1 Interplay: An In Vitro and In Vivo Study. J. Alzheimers Dis. 2016, 54, 737-750. [CrossRef]

113. Cordero, J.G.; Garcia-Escudero, R.; Avila, J.; Gargini, R.; Garcia-Escudero, V. Benefit of Oleuropein Aglycone for Alzheimer's Disease by Promoting Autophagy. Oxid. Med. Cell. Longev. 2018, 2018. [CrossRef]

114. Margheri, F.M.B.; Laurenzana, A.; Del Rosso, M.; Fibbi, G.; Cipolleschi, M.G.; Ruzzolini, J.; Nediani, C.; Mocali, A.; Giovannelli, L. Oleuropein aglycone attenuates the pro-angiogenic phenotype of senescent fibroblasts: A functional study in endothelial cells. J. Funct. Food 2019, 53, 219-226. [CrossRef]

115. Shamshoum, H.; Vlavcheski, F.; Tsiani, E. Anticancer effects of oleuropein. Biofactors 2017, 43, 517-528. [CrossRef]

116. Imran, M.; Nadeem, M.; Gilani, S.A.; Khan, S.; Sajid, M.W.; Amir, R.M. Antitumor Perspectives of Oleuropein and Its Metabolite Hydroxytyrosol: Recent Updates. J. Food Sci. 2018, 83, 1781-1791. [CrossRef]

117. Celano, M.; Maggisano, V.; Lepore, S.M.; Russo, D.; Bulotta, S. Secoiridoids of olive and derivatives as potential coadjuvant drugs in cancer: A critical analysis of experimental studies. Pharmacol. Res. 2019, 142, 77-86. [CrossRef]

118. Ruzzolini, J.; Peppicelli, S.; Andreucci, E.; Bianchini, F.; Scardigli, A.; Romani, A.; la Marca, G.; Nediani, C.; Calorini, L. Oleuropein, the Main Polyphenol of Olea europaea Leaf Extract, Has an Anti-Cancer Effect on Human BRAF Melanoma Cells and Potentiates the Cytotoxicity of Current Chemotherapies. Nutrients 2018, 10, 1950. [CrossRef]

119. Andreadou, I.; Mikros, E.; Ioannidis, K.; Sigala, F.; Naka, K.; Kostidis, S.; Farmakis, D.; Tenta, R.; Kavantzas, N.; Bibli, S.I.; et al. Oleuropein prevents doxorubicin-induced cardiomyopathy interfering with signaling molecules and cardiomyocyte metabolism. J. Mol. Cell. Cardiol. 2014, 69, 4-16. [CrossRef]

120. Karkovic Markovic, A.; Toric, J.; Barbaric, M.; Jakobusic Brala, C. Hydroxytyrosol, Tyrosol and Derivatives and Their Potential Effects on Human Health. Molecules 2019, 24, 2001. [CrossRef]

121. Pastor, A.; Rodriguez-Morato, J.; Olesti, E.; Pujadas, M.; Perez-Mana, C.; Khymenets, O.; Fito, M.; Covas, M.I.; Sola, R.; Motilva, M.J.; et al. Analysis of free hydroxytyrosol in human plasma following the administration of olive oil. J. Chromatogr. A 2016, 1437, 183-190. [CrossRef]

122. Jilani, H.; Cilla, A.; Barberá, R.; Hamdi, M. Improved bioaccessibility and antioxidant capacity of olive leaf (Olea europaea L.) polyphenols through biosorption on Saccharomyces cerevisiae. Ind. Crops Prod. 2016, 84, 131-138. [CrossRef]

123. Ahmad-Qasem, M.H.; Canovas, J.; Barrajon-Catalan, E.; Carreres, J.E.; Micol, V.; Garcia-Perez, J.V. Influence of olive leaf processing on the bioaccessibility of bioactive polyphenols. J. Agric. Food Chem. 2014, 62, 6190-6198. [CrossRef]

124. De Bock, M.; Thorstensen, E.B.; Derraik, J.G.; Henderson, H.V.; Hofman, P.L.; Cutfield, W.S. Human absorption and metabolism of oleuropein and hydroxytyrosol ingested as olive (Olea europaea L.) leaf extract. Mol. Nutr. Food Res. 2013, 57, 2079-2085. [CrossRef]

125. Kendall, M.; Batterham, M.; Callahan, D.L.; Jardine, D.; Prenzler, P.; Robards, K.; Ryan, D. Randomized controlled study of the urinary excretion of biophenols following acute and chronic intake of olive leaf supplements. Food Chem. 2012, 130, 651-659. [CrossRef] 
126. Žugčić, T.; Abdelkebir, R.; Alcantara, C.; Collado, M.C.; García-Pérez, J.V.; Meléndez-Martínez, A.; Jambrak, A.R.; Lorenzo, J.M.; Barba, F.J. From extraction of valuable compounds to health promoting benefits of olive leaves through bioaccessibility, bioavailability and impact on gut microbiota. Trends Food Sci. Technol. 2019, 83, 63-67. [CrossRef]

127. Mosele, J.I.; Martin-Pelaez, S.; Macia, A.; Farras, M.; Valls, R.M.; Catalan, U.; Motilva, M.J. Faecal microbial metabolism of olive oil phenolic compounds: In vitro and in vivo approaches. Mol. Nutr. Food Res. 2014, 58, 1809-1819. [CrossRef]

128. Santos, M.M.; Piccirillo, C.; Castro, P.M.; Kalogerakis, N.; Pintado, M.E. Bioconversion of oleuropein to hydroxytyrosol by lactic acid bacteria. World J. Microbiol. Biotechnol. 2012, 28, 2435-2440. [CrossRef]

129. Aponte, M.; Ungaro, F.; d'Angelo, I.; De Caro, C.; Russo, R.; Blaiotta, G.; Dal Piaz, F.; Calignano, A.; Miro, A. Improving in vivo conversion of oleuropein into hydroxytyrosol by oral granules containing probiotic Lactobacillus plantarum 299v and an Olea europaea standardized extract. Int. J. Pharm. 2018, 543, 73-82. [CrossRef]

(C) 2019 by the authors. Licensee MDPI, Basel, Switzerland. This article is an open access article distributed under the terms and conditions of the Creative Commons Attribution (CC BY) license (http://creativecommons.org/licenses/by/4.0/). 